\title{
Oyun, Bilişsel Gelişim ve Toplumsal Dünya: Piaget, Vygotsky ve Sonrasi
}

\section{Ageliki Nicolopoulou}

\section{Çev: Dr. Melike Türkân Bağlı ${ }^{* *}$}

ÖZ: Bu makale, oyun ve bilişsel gelişim araştırmalarına eleştirel bir bakışın yanısıra bu bakışı aydınlatan iki büyük kuramsal çerçevenin bir analizini ortaya koymaktadır.. Son zamanlara kadar bu alandaki başat etki, oyuna yaklaşımı, bilişsel gelişim kuramının bütünleyici bir parçasını oluşturan Piaget'in olmuştur. Pigaetci araştırma programı, tükenmiş olmaktan uzak olmasına karşın, bu yaklaşımda sosyokültürel boyutun bulunmaması, gelişim kuramı giderek büyük bir alternatif çerçeve olarak ortaya çıan Vygotsky'nin etkisi için bir alan yaratmıştır. Ancak bu ikinci araştırma akımı, bugüne kadar Vygotskyci "esin"i sınırlı ve yetersiz bir biçimde dikkate almıştır. Özellikle, etkileşime çok sınırlı olarak odaklanılmış ve oyun bağlamını tanımlayan ve biçimlendiren daha büyük sosyokültürel öğelerle ilgilenilmemiştir. Bu makale, daha güçlü bir araştırma bakışaçısının anahatlarının önerilmesiyle sonuçlanmaktadır. Diğer kaynaklar arasında bu yaklaşım, kısmen Piagetci ve Vygotskyci perspektiflerdeki belirli öğelerin Durkheim ve Freud'daki kökleriyle yeniden bağlantılandırılması ve Geertz tarafindan savunulan kültürel yorumlama yaklaşımının kullanılması yoluyla, Piagetci ve Vygotskyci yaklaşımların kendi içlerindeki keşfedilmemiş bazı olanaklar üzerine kurulmaktadır.

Son yıllarda çocukların oyunları ve gelişimdeki rolleriyle ilgili çalışmalara artan bir ilginin olduğu görülmektedir. Bu geliş̧en ilgi yalnızca

\footnotetext{
* Nicolopoulou, A. (1993). Play, cognitive development, and the social world: Piaget, Vygotsky, and beyond. Human Development, 36(1), 1-23.

${ }^{* *}$ Ankara Üniversitesi Eğitim Bilimleri Fakültesi Araştırma Görevlisi
} 
psikolojide değil, eğitim, antropoloji ve sosyoloji gibi alanlarda da kendisini belli etmektedir. Bu ilgi yalnızca araştırmacıları değil, doğrudan doğruya çocuklarla ilgilenen politika üreticilerini ve bir dizi uygulamacıyı da içine almaktadır. Bu eğilimin bir göstergesi, Handbook of Child Psychology'nin en son baskısının (Mussen ve Hetherington, 1983), oyun üzerine araştırmaları gözden geçiren bir bölümü kapsayan ilk kitap olmasıdır; kitabın yazarları bu yeniliği, kısmen, bu konuyla ilgili disiplinlerarası araştırmaların sayısının son yıllarda artmasına bağlamaktadırlar (Rubin, Fein ve Vandenberg, 1983).

Uzun dönemde bu farklı disiplinlerin (ve alt-disiplinlerin), çocukların oyunlarıyla ilgili düşünce ve bulgu alışverişi ve sentezi aracılığıyla, birbirlerine katacakları çok şey olacaktır. Ancak en verimli alışverişin oluşabilmesi için her bir disiplinin bu değişime, kendi mevcut bilgi hacminin bütüncül bir tablosunu ve yapılmakta olan araştırmalara yol gösteren kuramsal perspektifin (ya da perspektiflerin) duyarlıklarını getirmesi gerekmektedir. Gelişim psikolojisindeki oyunla ilgili araştırmalara bakıldığında, durum bu yönlerden büyük ölçüde sorunlu durumdadır. Oyuna yönelik araştırmaların hızlı bir biçimde artışı bazı değerli sonuçlar üretmiş olmasına karşın, bu araştırmaların genel örüntüsü dağınık ve bağlantısızdır ve çoğunun, açık bir şekilde düşünülerek tasarlanmamış olduğu ya da gelecek vâdeden kuramsal bir gündemi izlemediği görülmektedir. Bazı araştırma yaklaşımları genellikle daha geniş bir ilgili çerçeveye göndermede bulunmaktadır, ancak araştırmacıların daha geniş olan bu çerçevenin mantığı ve doğurguları üzerinde dikkatli bir biçimde durup durmadıkları, bu çerçevenin sahip olduğu en güçlü ya da en uygun öğeleri kullanıp kullanmadıkları ya da bu çerçevenin kuramsal kaynaklarını en etkili yollarla çocukların oyunlarıyla ilgili olarak ortaya çıkan belirli sorunlara uygulayıp uygulamadıkları her zaman açık değildir. Dolayısıyla şu an, gelişim psikolojisindeki oyun araştırmalarındaki farklı yaklaşımları değerlendirmek, bu yaklaşımları yönlendiren kuramsal bakışaçılarını ifade etmek ve bu bakışaçılarının en değerli öğelerinin geliştirilebileceği ve kullanılabileceği yollar üzerinde düşünmeye başlamak için uygun bir zamandır.

$\mathrm{Bu}$ makalede üstlendiğim görev budur. $\mathrm{Bu}$ alandaki en ilginç ve en umut verici araştırmalardan ele aldıklarımın tutarlı bir görünümünü sunmaya çalışacağım ve oyunla bilişsel gelişim arasındaki ilişkiyle ilgili araştırmalara yol gösteren önemli kuramsal çerçeveleri değerlendireceğim. Bu değerlendirmeyi yapmak, oyun araştırmalarına yönelik perspektiflerin meydana çıkartılmasına, bu araştırmaların güçlülük ve zayıflıklarının değerlendirilmesine ve daha da önemlisi, ilerideki araştırmalarda hangi yaklaşımların yararlı bir biçimde izlenebileceğinin belirlenmesine yardımcı olacaktır. Özellikle mevcut yaklaşımların doğasında bulunan keşfedilmemiş olanaklardan bazılarının, hem araştırmacıların, hem de uygulamacıların ilgilerine yönelik olarak, çocukların oyunlarıyla ilgili daha güçlü bir 
araştırma programına katkıda bulunmak üzere nasıl geliştirilebileceğini ortaya koyacağım.

Oyunla bilişsel gelişim arasındaki ilişki, otuz yıldan fazla bir zamandır, oyun konusunda yapılan pek çok psikolojik araştırmada kilit bir konu olmuştur. İki büyük kuramsal çerçeve bu araştırmaları şekillendirmede ve örgütlemede baskın bir rol oynamıştır. Uzun bir dönem boyunca başat etki, açık bir biçimde oyuna yaklaşımı geniş bilişsel gelişim kuramının bütünleyici bir parçasını oluşturan Piaget'in olmuştur. Piagetci araştırma programı tükenmiş olmaktan uzak olmasına karşın, bu programın sınırlılıklarına ilişkin kanı giderek yaygınlaşmaktadır ve Piaget'in gelişim kuramı artan boyutlarda eleştirilere hedef olmaktadır. Özellikle eleştirilerin bir boyutu, Piagetci çerçevenin toplumsal ve kültürel etmenlere yönelttiği ilginin yetersiz olduğunu önesürmektedir. $\mathrm{Bu}$ etmenlere sistematik bir biçimde yönelen oyun araştırmaları son yıllarda düzenli olarak yaygınlık kazanmaktadır. Bu araştırmalar pek çok kaynaktan yararlanırken, bu etmenleri artan bir biçimde aydınlatan ve birleştiren kuram, Vygotsky'nin sosyokültürel yaklaşımlı zihinsel gelişim kuramıdır.

Bu makalede savunulan nokta, Vygotsky'nin kuramsal çerçevesinin en azından Piaget'in yaklaşımını yararlı bir şekilde tamamladığı ve oyun araştırmalarını biçimlendirmede gittikçe daha önemli hale geldiğidir. Savunacağım yaklaşım, yoğun bir biçimde Vygotskyci bakışaçısından yararlanmaktadır ve dolayısıla ben de Vygotsky'nin, oyunu toplumsal bir etkinlik olarak gören anlayışının, bilişin sosyokültürel temellerine ilişkin daha geniş bir ilgi alanıyla nasıl bağlantılı olduğunu açıklığa kavuşturma girişiminde bulunacağım.

Oyun araştırmalarının önemli bir bölümü, Freudçu kuramdan çeşitli biçimlerde yararlanmaktadır. $\mathrm{Bu}$ makalede bu yaklaşımı büyük ölçüde gözardı etme nedenim, yaklaşımın genel olarak bilişsel gelişim sorunlarına odaklanmamış olmasıdır. Yine de Freudçu bakışaçısının hem Piaget hem de Vygotsky tarafından değinilen, ancak üzerinde yeterince durulmayan bazı konularının çocukların oyunlarına bilişsel açıdan yaklaşan araştırmalarla yararlı bir şekilde bütünleştirilebileceğini önesüreceğim.

\section{Piaget Çağı}

1970'lerde oyunla ilgili psikolojik araştırmalardaki canlanma, büyük ölçüde, Piaget'in (1945/1962) yeni ufuklar açan Çocuklukta Oyun, Düşler ve Taklit (Play, Dreams and Imitation in Childhood) adlı çalışmasından kaynaklanmıştır. Piaget'in anlayışı, oyunu doğrudan doğruya bilişsel süreçler ve bilişsel gelişim bağlamına yerleştirmektedir. Piaget için oyun, dışarıdan

gözlemlenebilen yollarla diğer davranışlardan açık bir biçimde ayrılan farklı bir davranış türü değildir. Zihinsel yaşamda oyun öğesini belirleyen şey, 
daha çok, bir dizi etkinlikte az ya da çok ifadesini bulabilen, davranışa doğru özel bir yönelimdir. Bu yönelim, Piaget'in "özümleme" olarak adlandırdığ 1 zihinsel etkinlik eğilimindeki çok ya da az özel üstünlüğü tarafından tanımlanmaktadır.

\section{Piaget'in Kuramında Oyuna Bakış}

Piaget'e göre, zekânın her eylemi birbirine karşıt iki eğilim olan özümleme ile uyma arasındaki dengelenim tarafından belirlenmektedir. Özümlemede kişi olayları, nesneleri ve durumları, örgütlü zihinsel yapıları kuran mevcut düşünme biçimlerinin içine almaktadır. Uymada, mevcut zihinsel yapılar dişsal çevrenin yeni yönleriyle birleştirilmek için yeniden örgütlenmektedir. Zekâ eylemiyle kişi, dışsal gerçekliğin gerekliliklerine uyum sağlarken, aynı zamanda zihinsel yapılarını eksiksiz olarak korumaktadır. Oyun ise tersine, özümlemenin uymaya üstünlügüyle belirlenmektedir; kişi, olayları ve nesneleri, mevcut zihinsel yapılarının içine almaktadır.

Piaget, birbirini izleyen üç sistemi -alıştırma oyunu, sembolik oyun ve kurallı oyun- tanımlayarak çocukların yaşamın ilk yedi yılındaki oyunlarının evriminin anahatlarını çizmiştir. Bu sistemler duyu-devinim, işlemöncesi ve somut işlem zekâlarının birebir karşılıklarıdır. Alıştırma oyunu ilk olarak ortaya çıkan oyundur ve yaşamın ilk 18 ayı boyunca baskındır. Yerleşmiş eylem ve manipülasyon dizilerinin, pratik ya da araçsal amaçlarla değil, motor etkinliklerdeki ustalıktan elde edilen saf haz için tekrarlanmasını kapsamaktadır. Piaget'e göre, bu oyun biçimi çocuk tarafindan kazanılan hemen hemen tüm duyu-devinim şemalarından doğmakta ve temel olarak çocuğun nesneleri kullanması üzerine odaklanmaktadır.

$\mathrm{Bu}$ uygulama alıştırmalarının sayısı ve önemi bir yaş dolaylarında azalmaktadır. Çoğu zaman bunların aşağıdaki biçimlerden bir ya da daha fazlasına dönüştükleri görülmektedir: a) Çocuk, saf tekrardan, önce rastlantısal ve sonra da amaçlı eylem ve manipülasyon kombinasyonlarına geçer; bu gerçekleşir gerçekleşmez çocuk, hedefler belirler ve alıştırma oyunları yapılara dönüştürülür. b) Çocuğun ortaya koyduğu yapılar ya da eylem dizileri sembolik hale geldiği için saf alıştırma oyunları da sembolik hale gelebilir, ya da en azından "sembolizmle biraradadır". c) Oyun etkinlikleri kolektif duruma gelebilir ve kurallar kazanabilir, ve dolayısiyla "kurallı oyunlar"a dönüşebilir. Bu üçüncü dönüşüm, gerçekleşecek olan son dönüşümdür.

Sembolik oyun, yaşamın ikinci yılı boyunca tasarımlama ve dilin doğuşuyla birlikte görülmektedir. Piaget'e göre "-mış gibi oyun", başlangıçta doğuştan gelen/ bireye özgü oyun sembollerinin (idiosyncratic ludic symbols) kullanımını içeren yalnız bir sembolik etkinliktir. Ortak sembollerin kullanıldığı sembolik oyun, yaşamın üçüncü yılının son 
dönemlerine kadar ortaya çıkmamaktadır. Piagetci modelde, ilk -mış gibi oyun, kombinasyonları zamanla değişen şu öğeleri kapsamaktadır: a) Bağlamdan uzaklaşmış davranış (örneğin, "boşluk içinde", uyumak, yemek yemek ya da "boş bir kaptan" içmek gibi tanıdık bir davranışta bulunmak) b) Kendine göndermede bulunmaktan bir başkasına göndermede bulunmaya doğru değişmeler (örneğin, kendisinin uyumak üzere yatması yerine oyuncak ayıyı yatırması). c) İkame nesnelerinin kullanımı (örneğin, bebek yerine bir blok). d) Sırasal kombinasyonlar (örneğin, çocuğun, tek bir eylemi taklit etmek yerine -mış gibi olarak bütün bir senaryoyu kurması).

Piaget'e göre, çocuk sembolik oyunun gelişimiyle birlikte, gerçekliği fiziksel olarak manipüle etmenin verdiği basit doyumun giderek ötesine geçmektedir. Çocuk artan bir biçimde, sembolik çarpıtmalar ve yer değiştirmeler sürecinde dişsal gerçekliği sembolik olarak egoda özümleyebilmektedir. Dolayısıyla sembolik oyun, ödünleme, dilek-doyum, çatışmaların ortadan kaldırılması vb. aracılığıyla fantazi doyumun gerçekleşmesi için kullanılmaktadır. Sembolik oyun, çocuğun, egoyu gerçekliğe bağlı kılmakta giderek daha yeterli duruma gelmesiyle birlikte dört yaş dolaylarında azalmaktadır.

Üçüncü tür oyun, Piaget'in Çocuklukta Oyun, Düşler ve Taklit'te çok kısaca değerlendirdiği, toplumsallaşmış bireyin oyuncu (ludic) etkinliğe geçişini belirleyen kurallı oyundur. Piaget'in tartıştığ bu oyun türü, 4 ile 7 yaşları arasındaki dönemden önce seyrek olarak oluşmakta ve baskın olarak 7 'den 11 yaşa kadar olan dönemde görülmektedir. Piaget, kuralların en az iki bireyin etkileşimini öngördüğünü ve bunların toplumsal grubu düzenleme ve bütünleştirme işlevinde bulunduğunu vurgulamaktadır (Piaget'in yararlandığ 1 daha geniş kapsamlı bir argüman, Durkheim'ın özellikle 1925/1973 arasındaki yazılarında bulunmaktadır). Kuralların kendisi dikkate alındığında, Piaget bunları, yukarıdan aktarılanlar ve kendiliğinden kurulanlar olarak iki kategoriye ayırmaktadır. Bu iki kurallı eylem arasındaki karşıtlık, en fazla, Piaget'in (1932/1965) bu konularda gerçekten geniş ufuklar açan ve çocukların bilye oyunundaki kavrayışlarının kapsamlı analizinin övünç verici bir örneği olan Çocuğun Ahlâksal Yargısı (The Moral Judgment of the Child) adlı eserinde ortaya konmaktadir.

Piaget, Çocuklukta Oyun, Düşler ve Taklit'te geçici anlaşmalara dayalı kendiliğinden kurallı oyunlara odaklanmaktadır. Piaget, kendiliğinden kurallı oyunları, hem saf alıştırma oyunlarının hem de zaman zaman sembolik oyunların toplumsallaşmasının sonucu olarak değerlendirmektedir. Yine de, Piaget'in kurallı oyunların psikolojik önemini kabul etmesi, bu oyunlarda önceki oyun biçimlerinde sözkonusu olan işlevlerin sürdüğünü vurgulamaktadır. Piaget kurallı oyunlarda, bütün oyunlardaki ilke olan ego içerisinde özümleme ile toplumsal yaşam arasında ince bir dengelenim görmektedir. Diğerlerine karşı bireysel bir zafer kazanma şansında zihinsel 
bir doyum vardır, ancak bu doyum onur ve adil oyun ilkesini sağlayan oyun kuralları tarafından "meşru" kılınmaktadır.

Özetle, Piaget oyun gelişiminin saf bireysel süreçlerden ve doğuştan gelen özel sembollerden, toplumsal oyuna ve ortak sembolizme doğru ilerlediğini belirtmektedir. Oyun, çocuğun zihinsel yapısından kaynaklanır ve ancak bu yapı tarafindan açıklanabilir. Oyun, özümlemenin uyum sağlamadan farklılaşması ile başlayan bir etkinlik biçimidir ve özellikle özümleme kendi başına işlevde bulunabildiği zaman ortaya çıkar. Tasarımlama yeteneğinin doğuşuyla birlikte, özümlemenin kendisi için yapılan özümleme, yalnızca çarpıtıcı değil, aynı zamanda önceden tasarlanmış -mış gibi yapmanın kaynağı durumuna da gelir. Dolayısıyla, mış gibi oyun, çocuğun, geçmiş yaşantılarını, egonun gerçekliğe boyun eğmesi için değil doyuma ulaşması için bastırmasını sağlar. Bu bakımdan, oyun, gerçekliği nesnel olarak kavrama gereksiniminden çok, sempatik ve yumuşak bir biçimde anlama gereksinimini yansıtmaktadır (Piaget'in terminolojisinde "pathic" zihniyet, "gnostic" zihniyete karşıttır).

\section{Piagetci Oyun Araştırmaları ve Olumsuzlukları}

Çok sayıda araştırmacı Piagetci modeli bir sıçrama tahtası olarak kullanmıştır ve bir yandan daha sistematik gözlemler elde ederken, bir yandan da Piaget'in belli iddialarından pek çoğunu katı deneysel denemelere tabi tutmaya girişmiştir (literatürün daha kapsamlı bir dökümü için bakınız: Fein, 1981; Fein ve Rivkin, 1986; Rubin, 1980; ve Rubin ve ark., 1983). Araştırmaların büyük bölümü, son on yıl içinde oyun literatüründe başat bir alan haline gelen -mış gibi oyun üzerine odaklanmıştır. Dikkat çeken konulardan bazıları, -mış gibi oyunun ortaya çıkışının ve azalışının belirlenmesini (örneğin, Bates, Benigni, Bretherton, Camaioni ve Volterra, 1977; Kessen ve Fein, 1975; Rosenblatt, 1977) ve -mış gibi biçimlerinin bilişsel olgunluk ve dil kazanımlarına bağlı olarak nasıl sıralandığını (örneğin, Fenson ve Ramsay, 1980; Nicolich, 1977) içermektedir. Piaget tarafindan tanımlanan pek çok etmen, [artan bir biçimde, bağlamdan uzaklaşmış davranış yönünde hareket (örneğin, Fein ve Apfel, 1979; Fein ve Moorin, 1985; Fenson, Kagan, Kearsley ve Zelazo, 1976; Kagan, Kearsley ve Zelazo, 1978; Lowe, 1975); kendine göndermede bulunmaktan başkasına göndermede bulunmaya doğru değişme (örneğin, Fein ve Apfel, 1979; Fenson ve Ramsay, 1980; Inhelder, Lezine, Sinclair ve Stambak, 1972; Lowe, 1975; Watson ve Fisher, 1977); ve nesneleri birbirleri yerine ve tasarımlama için kullanma yeteneğinin gelişmesi (örneğin, Fein, 1975; Fein ve Apfel, 1979; Fein ve Robertson, 1975; Inhelder ve ark., 1972; Jackowitz ve Watson, 1980; Lowe, 1975; Watson ve Fisher, 1977)] özellikle bütünüyle araştırılmıştır. 
$\mathrm{Bu}$ araştırmalar, çocukların oyunlarının, Piaget'in sadece kabaca ortaya koyduğu yönlerine ilişkin anlayışımızı büyük ölçüde zenginleştirmiş olmasına karşın, bu çalışmaların ciddi ve devamlı bir nitelik taşıyan sakıncalı tarafları da var olagelmiştir. Öncelikle, bu araştırmacılar oyun araştırmalarında yalnızca laboratuvar ortamını kullanmışlar ve yalnız nitelikteki -mış gibi oyunu analizlerinin tek nesnesi gibi görmüşlerdir. $\mathrm{Bu}$ sınırlılıkların üstesinden ancak yavaş bir biçimde ve kısmen gelinmiş durumdadır. Üstelik, araştırmacıların laboratuvar bulgularını, ev ve oyun alanı gibi doğal ortamlardan elde edilen gözlemlerle sistematik biçimde karşılaştırarak eleştirel bir gözle değerlendirdiklerine çok seyrek olarak rastlanmaktadır. Dolayısıyla laboratuvar ortamlarındaki gözlemler, çocuğun kendiliğinden oyununa ilişkin kavrayışımızı etkili bir şekilde zenginleştirmemiş olduğundan, oyun araştırmalarının bu bölümü araştırmanın esas nesnesinden ayrılmıştır -bu, öğretmenler ve diğer uygulamacılar arasında güçlü bir biçimde hissedilen bir duygudur. Aslında, araştırmacılar oyun boyunca orada olmalarına karşın kendi başına oyuna varmayan ayrıntıcı gözlem davranışları uğruna, yalıtılmış gibidirler.

Araştırma uygulamalarındaki bu eğilimler, zamanla, araştırmacıların oyun kavramlaştırmalarını daraltmalarına katkıda bulunmuştur. Dolayısıyla oyun Piaget'in başlangıçta ortaya attığı gibi, bir etkinlik biçimi ya da yönelimi olarak görülmekten çok, bireysel davranışsal bir eğilim (örneğin, Rubin ve ark., 1983), bilişsel bir beceri (örneğin, Fein, 1981) ve hatta kendi başına bilişsel bir süreç (örneğin, Vandenberg, 1980) olarak görülme eğilimindedir (buna paralel bir tartışma için bakınız, Cohen, 1987). Üstelik, davranışsal ve bireysel olarak sınırlandırılmış bu oyun görüşü, çalışmaları, oyun ile, problem çözme, dil gelişimi ve sosyal biliş gibi diğer psikolojik işlevler arasında doğrudan ilişkiler kurabilmek için sik sik oldukça basitleştirilmiş araştırmalara doğru yöneltmek eğiliminde olmuştur (örneğin, Rubin ve ark., 1983; Sylva, Bruner ve Genova, 1974; Vandenberg, 1980).

Bunlardan ve göstergeleri öncelikle yöntemsel olan diğer problemlerden başka, bu araştırmaları aydınlatan kavramsal yaklaşımların altında daha temel bir eksiklik vardır. Bu eksikliğin bir bölümü, Piaget'in kendisinden kaynaklanmaktadır; ancak durum, onun izleyicileri tarafindan daha da olumsuz bir hale getirilmiştir. Çocuklukta Oyun, Düşler ve Taklit, Piaget tarafindan, Çocuğun Ahlâksal Yargısı'ndan on yıldan fazla bir zaman sonra yazılmış ve ilk çalışmalarla ilgili olmasına karşın, yöntem ve entellektüel kaygılar açısından bu çalışmalarla benzerlik göstermektedir. Sonuç olarak, Çocuklukta Oyun, Düşler ve Taklit, varlıkları Piaget'in sonraki çalışmalarında daha zayıf olarak bulunan ya da hiç bulunmayan iki düşünürün -Freud ve Durkheim'ın- güçlü etkisini göstermektedir. Piaget'in, duygusal öğeyi okuyucuların sıklıkla gözden kaçırmalarını kolaylaştıracak kadar az tartışmış olmasına karşın, Piaget'in ikinci oyun evresinin analizi, 
fantazinin rolüne ve psikolojik etkinlik ve gelişimde duygusal öğenin yerine ilişkin vurgusuyla bilinmektedir. Giderek tek yönlü bir biçimde (yeni-Kantç1 akılcılık yönünde) çok daha fazla bilişsel bir hale gelen Piaget'in sonraki çalışmalarında bu vurgunun gerçek karşılıkları bulunmamaktadır. Diğer yandan, üçüncü evre analizleri, daha dikkatli bir biçimde ele alınan Çocuğun Ahlâksal Yargısı'nda olduğu gibi, Durkheim'ı ve özellikle Durkheim'ın bireysel gelişimi toplumsal bir bağlama yerleştirme israrını eleştirel bir şekilde incelediğini göstermektedir. Ancak Piaget'in toplumsal bağlamı ele alış biçimi zamanla daralma eğilimindedir. Çocuğun Ahlâksal Yargısı'nda bile, Piaget'in toplumu ve toplumsal yaşamı etkileşime indirgeme eğilimi vardır, fakat analizinde -azalmış olmakla birlikte- en azından toplumsal bir öğe bulunmaktadır. Yine de, Çocuklukta Oyun, Düşler ve Taklit'te temel amaç, Piaget'in girişte açıkça belirttiği gibi, bireysel, ancak çeşitli tasarımlama sistemlerinde evrensel ve yaygın bir mekanizma olarak sembolik işlevin doğuşunu tanımlamaktır. Üstelik Piaget bu mekanizmanın varlığının, bireylerarası herhangi bir iletişim için, dolayısıyla ortak anlamların oluşumu ya da kazanımı için bir önkoşul olduğunu göstermek istemektedir. O halde, Piaget'nin üçüncü evreyi tanılaması manidardır; ancak ortak anlamlara ve kurallı oyunlara yalnızca üstünkörü bir şekilde yaklaşmaktadır. Sonraki çalışmalarında toplumsal ve duygusal kaygılar temel bir biçimde kaybolmaktadır. Piagetci araştırmacılar da ustalarını bu bakımdan büyük ölçüde izlemişlerdir.

Piaget'in -bilginin yaratılması ve kazanılması için aralarında karşılıklı etkileşim ve birlik olması gereken- özümleme ile uyma arasındaki analitik ayrılığı ortaya koyma eğiliminden kaynaklanan bir başka sorun, doğrudan, sırasıyla, oyun ve taklit psikolojik etkinlikleri arasındaki karşıtlığa dayanmaktadır (Piaget, en azından 3 yaşına kadar böyle olduğunu düşünmektedir. Bu bağlamda 3. yıldan sonra, özümleme ile uyma arasındaki ayrımın, bütünüyle analitik olduğunu önesürmektedir; ancak, bu çerçeveye bağlı kalarak daha ileriki yaşlarda oyunu nasıl ele alacağımız açık değildir). $\mathrm{Bu}$ girişim, birçok başka sorunu ortaya çıkarmaktadır. $\mathrm{Bu}$ sorunlardan birincisi, oyun ve taklit psikolojik etkinliklerinin birbirinden yalıtılmış ve tek boyutlu analitik öğelere indirgenmiş olmalarıdır. Dolayısıyla, Piaget oyunu "uç" özümleme ile, taklidi de "uç" uyma ile özdeşleştirmektedir. Üstelik, oyunun taklitten böyle yalıtılmasının yeni bilgilerin üretilmesine katkıda bulunduğu düşünülemez. Piaget'e göre, bu kuramda özümleme ile uymanın eşgüdümünü gerçekleştiren tek etkinlik türü oldukları için, yalnızca zekâ eylemleri bunu yapabilir. Sonuç olarak Piaget, oyunu zaten var olan psikolojik yapıların anlatımına indirgeyerek, oyunu yeni bir gelişim bağlamı

olarak görme firsatını ortadan kaldırmaktadır (bu genel görüşle ilgili kısmi bir eleştiri için bakınız: Schwartzman, 1978 ve Sutton-Smith, 1971). 
Piaget'in kavramlaştırmasının neden olduğu kuramsal zayıflık, oyun ve taklidin kısaltılmış biçimlerini kabul eden ve bunlar arasında yoğun bir alışverişi yeniden kurmaya hiç çalışmamış olan Piaget'in izleyicileri tarafindan büyük ölçüde gözden kaçırılmıştır. Üstelik Çocuklukta Oyun, Düşler ve Taklit'in psikologlar arasında kabul görmesi, açıkça, bütünüyle Piaget'in sonraki çalışmalarının hamlesiyle mümkün olmuştur; çünkü duygusal öğeler ve toplumsal yaşam, Piaget'in bu kitapta önemsediğinden de az dikkat çekmiştir. Piagetci oyun araştırmalarında özellikle sosyokültürel boyutun olmaması, bu boyutu merkezi bir boyut olarak gören Vygotsky'nin etkisi için bir alan yaratan nokta olmuştur.

\section{Vygotsky: Oyunu Araştırmak}

Psikolojik oyun araştırmalarının yönünü biçimlendirmiş olan ikinci önemli etki Vygotsky'ye atfedilebilir. Son yıllarda Vygotsky'nin adı Piaget'le karşılaş̧tırmada ve karşıtlaştırmada giderek daha sik bir biçimde hatırlanmaktadır. Aslında Vygotsky'nin yaklaşımı, araştırmacıların, zihnin toplumsal olarak biçimlenmesine ilişkin ilgilerini aydınlatan ve biraraya getiren Piaget'in kapsamlı bilişsel kuramına karşı yaşayabilir bir alternatif olarak ortaya çıkıyor gibi görünmektedir.

\section{Vygotsky'nin Kuramında Oyuna Bakış}

Vygotsky'nin oyun araştırmaları üzerindeki etkisi, Piagetci etkiden çok daha karmaşık ve yaygındır. Bu farklılık kısmen Vygotksy'nin yazılarının doğasından, kısmen de onun temel mesajıyla özdeşleşmiş olanlar üzerindeki etkisinin türünden dolayıdır. Yazılarının sezgilerle ve aydınlatmalarla dolu olduğu gerçeğine karşın, bunlar çoğunlukla kabataslak ve bazen de tamamlanmamış durumdadırlar. Oyunla ilgili önemli çalışmalarından İngilizce'de bulunanları, aslında bir ders olarak verilen ve oyuna alternatif bir yaklaşımın çarpıcılığını içeren yalnızca tek bir makaleyle kısıtlıdır (Vygotsky, 1933/1967, Bruner, Jolly ve Sylva, 1976 tarafindan yeniden basılmıştır, ve 1978 'de Cole ve arkadaşları tarafından yayınlanan Vygotsky'nin çalışmalarını içeren bölümde kısmen yeniden yer almıştır).

Vygotsky, Piaget'ten farklı olarak, sistematik ve dikkatli bir biçimde belgelenmiş bir araştırma programı önermemektedir. Daha çok, kabul edilmesi durumunda, psikolojik alana yönelik yeni bir bakış biçiminin gelişmesine yardım edecek bir dizi kavram önermektedir. Bruner'in (1986) belirttiği gibi, Vygotsky bir esin kaynağı olarak hizmet etmektedir ve sadece belirli denencelerin alıntılandığı bilimsel bir toplulukta Vygotsky'nin sözü edilen parlak fikirlerini anmak zordur. Vygotsky'nin oyun araştırmaları üzerindeki etkisinin, sonuç olarak onun çalışmalarından doğrudan söz 
edildiğinde ortaya çıkacak etkiden daha büyük olduğu, ve özellikle 1933 ile 1967 yılları arasındaki makalelerinin buna inanmamızı sağlayacağı görüşündeyim. Paradoksal bir biçimde, daha sonra tartışacağım gibi, genel olarak Vygotsky'nin derin etkisinden söz etmeyenlerin sayısı söz edenlerin sayısından daha fazladır.

Vygotsky'nin oyunla ilgili görüşlerinin burada sunulan anahatları, temel olarak onun 1933-1967 makaleleri üzerine kurulmuştur; ancak tartışmayı aydınlatmak için onun geniş kuramsal bakışaçısından yararlanmaktayım. Vygotsky'ye göre, gerçek oyun 3 yaş dolaylarında, sosyodramatik oyundan ayrı tutmadığı -mış gibi oyunla başlar. Ona göre, oyun daima toplumsal bir sembolik etkinliktir. Oyun tipik bir biçimde tek bir çocuktan fazlasını kapsamaktadır; ve oyun parçalarındaki konular, öyküler ya da roller, çocukların kendi toplumlarının sosyokültürel malzemelerini kavrayışlarını ve oyun amacıyla kullanımlarını ortaya koymaktadır. Dolayısıyla küçük bir çocuk yalnız başına oynadığında bile, Vygotsky bu tür oyunun, oyunun konuları ve parçaları sosyokültürel öğeleri ifade ettiği için önemli bir biçimde toplumsal olduğunu düşünmektedir. Üstelik Vygotsky, yalnız oyunun bu türünün, tek katılımcıdan daha fazla katılımcıyı içeren oyundan sonra geliştiğine inanmaktadır.

Vygotsky'nin oyunun temel olarak toplumsal karakteri üzerinde vurgulamada bulunmasını anlamak için, psikolojik kuramının daha geniş çerçevesi üzerinde kısaca durmamız gerekmektedir. Vygotsky'nin başlangıç noktası, küçük çocuklar belirgin bir biçimde insan işlevlerine dayanak oluşturmaya hizmet eden birçok fizyolojik ve psikolojik eğilimlerle donanmış bir biçimde doğmalarına karşın, yeteneklerinin büyük ölçüde kültürel pratikler ve kendilerini içinde buldukları topluluğun düşünce sistemleri tarafından biçimlendiriliyor olmasıdır. Diğer bir deyişle, Vygotsky, çocuğun (Piaget'in ifade etme eğiliminde olduğu izlenim olan) kabataslak bir biçimde kavramsal bir dünya yaratma durumunda olduğunu kabul etmemektedir. Aksine, çocukların, anababalar, diğer yetişkinler (hatta araştırmacılar) ve akranları tarafından kendilerine aktarılan mevcut kültürel dünyanın kavramsal kaynaklarını benimsemeleri, bunları kendilerine mal etmeleri gerekmektedir.

Dolayısıyla, Vygotsky, "yüksek psikolojik işlevler"in gelişimini ve yaratımını açıklarken, kültüre ve kültürün sosyal etkileşim ve iletişim aracılığıyla aktarımına merkezi bir rol vermektedir. Vygotsky, çocukların yalıtılmışlık içinde gelişmediklerini, daha çok bir toplumsal çerçeve, daha kesin bir biçimde de, bir çerçeveler dizisi içinde geliştiklerini vurgulamaktadır. $\mathrm{Bu}$ çerçeveler, bir yandan bir bütün olarak toplumun ve belirli kurumlarının (örneğin, aile, okul, ekonomik pazar) toplumsal örgütlenmesi tarafından şekillendirilen sosyal ilişki ve etkileşim sistemlerince, diğer yandan da toplumun kültürel mirası olan ve ortaklaşarak 
ayrıntılı bir şekilde oluşturulan kavramsal ve sembolik sistemlerin oluşturduğu iki kilit unsur arasındaki bağlantı tarafından oluşturulmaktadır. Kültürün biçimlendirdiği kaynaklar, yalnızca belirli bilgi parçalarını değil, örgütleyici bilişsel yapıları da kapsamaktadır. (Yetkin ve şaşırtıcı biçimde benzer ve bağımsız olarak geliştirilmiş ve biraz farklı kuramsal bir gelenekten çıkan bir açıklama için bakınız: Geertz, 1973, s.33-83).

Bir çocuk, kültürel mirası taşıyan daha bilgili ve yetenekli akran ve yetişkinleri içeren toplumsal bir bağlam içinde öğrenir ve gelişir. Bu aktarım öncelikle dilin ve iletişimin kullanımıyla gerçekleştirilir; yazılı belgeler ya da diğer fiziksel, mekanik veya sembolik tasarımlamalar gibi kültürel olan insani (yapay) yapımların kullanılmasıyla desteklenir. $\mathrm{O}$ halde bu bakışaçısına göre psikolojik gelişim, toplumsal (bireylerarasıinterpsychological) düzlemden bireysel (bireyiçi-intrapsychological) düzleme doğru ilerliyor görünmektedir (Vygotsky, 1978, 1986, 1987; Wertsch, 1985).

Vygotsky'nin bilişsel gelişim kuramının temel kavramı, "çocuğun bağımsız problem çözme olarak belirlenen gerçek gelişim düzeyi" ile "yetişkin rehberliğinde ya da daha yetenekli akranlarla işbirliği yaparak problem çözme olarak belirlenen gizil gelişim düzeyi" arasındaki fark olarak tanımladığı 'yakınsak gelişim alanı' (zone of proximal development) dır" (1978, s.86). Vygotsky, toplumsal dünyanın çocuğun gelişimine rehberlik etmesi ve bu gelişimi uyarması sürecini ifade etmek amacıyla kullandığ bu kavramı ele alışında, toplumun anababalara ve öğretmenlere yüklediği özel rolü gerçekten de haklı bulmaktadır. Diğerleri içinde bu rol, dilbilimsel ve diğer sembolik sistemleri, bilişsel çerçeveleri ve somut bilgileri de kapsayan birikimli kültür kaynaklarının çocuklara sistematik bir biçimde aktarımını kapsamaktadır. Bu kaynaklar, çocukların dünyayı yorumlamalarına yol göstermekte ve onların karşılaştırdıkları çeşitli fiziksel ve sosyal görüngüleri sistemleştirmelerine yardımcı olmaktadır.

Dolayısıyla, "yakınsak gelişim alanı"nın gerçekleştirilmesi ortak bir kültürel çerçeve içindeki sosyal etkileşime bağlıdır. Bu etkileşim, hem öğretimi, hem de birlikte ortaya konan etkinliklerin diğer biçimlerini kapsayabilir. Üstelik Vygotsky, çocuğun, gizil gelişim düzeyine, dolayısıyla ilerlemekte olan gerçek gelişime uygun bir biçimde düzenlendiklerinde, en çok bu tür etkileşimlerden yararlandığ 1 yorumunu yapmaktadır. Rogoff ve Wertsch'in (1984) bize bildirdikleri gibi:

Vygotsky, "öğretimin tamamlanmış evrelere yönelik olmak zorunda olduğu" sayıltısına dayalı bir öğretim görüşünü eleştirmiştir. Onun yerine, "ögretimin yalnızca gelişimin önünde ilerlediğinde iyi olduğunu" öne sürer. Ögretim, o zaman, bir olgunlaşma evresindeki ve yakınsak 
gelişim alanındaki işlevleri uyandırır ve canlandırır". Bu bakımdan öğretim, gelişimde olağanüstü önemli bir rol oynamaktadır (s.3, orijinalinde italik).

Vygotsky'nin oyun analizini yerleştirdiği geniş kuramsal bağlam budur. Vygotsky, oyunun basit bir biçimde bilişsel gelişimi yansıttığını düşünmekten çok, bilişsel gelişime önemli bir biçimde katkıda bulunduğunu düşünmektedir ve oyunu temelde toplumsal bir etkinlik olarak görmektedir. Vygotsky, insanlardaki oyun etkinliğinin biyolojik temellerini, bu tür eğilimler hayvanlarda da gözlemlenebildiği ve sembolizm yeteneğinin insanların kalıtsal doğalarının bir parçası olduğunu kabul ettiği için kesinlikle yadsımamaktadır. Ancak bu yeteneklerin gerçekleşmesinin ve biçimlenmesinin, toplumsal grupların ortak ve ayrıntılı bir biçimde oluşturulmuş olan sembolik ve kuralsal sistemlerinin aracılık ettiği toplumsal bir süreci içerdiğini ve bu sürecin doğasının da psikoloji için önemli bir sorgulama konusu olduğunu belirtmektedir.

Buradan, Piaget'in bıraktığı yerden basit bir biçimde Vygotsky'nin devam ettiği ya da Vygotsky'nin toplumsal oyun analizinin Piaget'in toplumsalöncesi (presocial) oyun analizine doğrudan eklenebileceği sonucu çıkarılmamaktadır. Aksine, Vygotsky'nin görüşü, Piaget'in gelişimsel oyun ve taklit şemasına tamamen ve gerçek bir biçimde karşı çıkmaktadır. Eğer Vygotsky haklıysa, Piaget'in ilk oyun evrelerinin analizi üzerinde yeniden düşünülmesi gerekmektedir; çünkü Piaget'in "sembolik oyun" adını verdiği oyun zaten toplumsaldır; Piaget'in doğuştan geldiğini düşündüğü semboller gerçekte sosyokültürel öğeler tarafindan oluşturulmuştur ve bu sembollerin biraraya getirilme biçimleri kültürel olarak örüntülendirilmiştir.

Vygotsky, oyunu nitelerken, birbiriyle ilişkili iki temel öğenin varlığını vurgulamaktadır: a) İmgesel bir durum ve b) imgesel durumdaki dolaylı kurallar. Bir imgesel durum, sadece -mış gibi oyunun değil, aynı zamanda gizli bir biçimde bulunabilmesine karşın- kurallı oyunların da- belirleyici bir niteliğidir. Örneğin, oldukça soyut bir oyun olan satranç, yalnızca belirli ve kurallı bir biçimde hareket edebilen şah, vezir, at ve bunun gibi belirli aktörlerle doldurulmuş imgesel bir dünya tarafından yapılandırılmaktadır. Kurallar sistemi, aslında oyun ortamının kendisinin kurulmasına hizmet etmekte ve daha sonra da bu kural ve eylemler anlamlarını oyun ortamından almaktadırlar. Yine, kuralların varlığ oyunlar"ın değil, sözkonusu kurallar dolaylı olabilmelerine karşın, -mış gibi oyunun da belirleyici bir niteliğidir. Örneğin, çocukların davranışlarına, üstlendikleri roller nedeniyle konulan kısıtlamaları dikkate aldığımızda, bu dolaylı kurallar görünür hale gelmektedir. Çocuklar, "anne" ya da "baba" imiş gibi davrandıklarında, istedikleri herhangi bir davranışı gösteremezler, kavradıkları kadarıyla annelik ve babalık davranış kurallarını yakalamak ve bu kurallara uymak zorundadırlar. Burada önemli bir bilişsel çaba vardır: 
"Gerçek yaşamda çocuğun gözden kaçırdığı şey, oyunda bir davranış kuralı haline gelmektedir" (Vygotsky, 1933-1967, s.9). Kısacas1, -mış gibi oyun ve kurallı oyunlar tek bir ölçeğin iki ucudur ve Vygotsky uzun dönemli oyun gelişimini bu uçlar arasındaki -dolaylı kuralların olduğu doğrudan imgesel bir ortamdan (-mış gibi oyun), doğrudan kuralların olduğu dolaylı imgesel bir ortama doğru (kurallı oyunlar)- dereceli bir hareket olarak görmektedir.

Çocuğun -mış gibi oyunda imgesel bir ortamı yaratışı sözkonusu olduğunda, Vygotsky, yazılarını yazdığı siyasal ortam tarafindan bir parça açıklanabilecek nedenler dolayısıyla, Freud'dan doğrudan doğruya söz edememesine karşın, büyük ölçüde temelde Freudçu türde olan bir psikodinamik açıklamadan yararlanmaktadır. Bu ona, bu tür davranışların güdüsel temellerini saf bir biçimde bilişsel olarak görmekten çok, öncelikle toplumsal-duygusal olarak görme firsatını vermektedir. Vygotsky, okulöncesi yıllar boyunca hemen karş1lanamayacak çok sayıda gereksinimin ortaya çıktığını kabul etmektedir. Oyun, fantazilerin kullanılması yoluyla, gerçekleştirilemeyen isteklerin gerçekleştirilmesini sağlamaktadır. $\mathrm{Bu}$ gerçekleştirim, yalnızca belirli ve bilinçli isteklerin değil, daha genel ve belirsiz isteklerin doyurulmasını da kapsamaktadır. Leontiev'in (1959-1981) Vygotsky'nin görüşlerini değerlendirdiği yazılarında belirttiği gibi, bu isteklerin en önemlisi, çocukların yetişkinler gibi eylemde bulunmak ya da gerekli eylemlerden çoğunu gerçekleştirmek bakımından hâlâ yetersiz oldukları halde, kendi başlarına bir şeyler yapma dilekleri üzerinde odaklanmaktadır.

Üstelik Vygotsky, bu süreçte çocukların bu imgesel doyumu gerçekleştirmelerinin, bir derece "kendini denetleme"yi ve "o anki içtepiye karş1 eylemde bulunma"y1 -yani kurallara gönüllü olarak boyun eğmeyigerektirdiğini keşfettiklerini önesürmektedir (Vygotsky, 1933/1967). Dolayısıyla, çocuklar kurallı bir evrene gönüllü olarak boyun eğmeleriyle birlikte güç kazanmaktadırlar; bu, Vygotsky'nin üzerinde önemli bir etkisi olan ve kendisine Piaget'in Çocuğun Ahlâksal Yargısı adlı kitabı aracılığıyla aktarılmış görünen oldukça Durkheimcı bir düşüncedir (Vygotsky, 1933/1967, s.10). Çocuklar, basit bir -mış gibi oyununda rol almak yoluyla bile, kendilerini oyunun kurallarına teslim ettiklerinde, kendilerini oyun dünyasına taşıyarak dış ortamsal sınırlamalardan bağımsızlaşmaktadırlar. Dolayısıyla oyun kuralları, "Piaget'in söylediği gibi, kendini sınırlamanın ve kendi kendini yönetmenin (self-determination) kuralları" haline gelmektedir (Vygotsky, 1933/1967, s.10). Sonuçta çocuklar, oyun aracilığıyla kendi isteklerini gerçekleştirmenin, kendi seçtikleri kurallara gönüllü olarak 
uymayı gerektirdiğini ve bireysel doyumlarının kurallı etkinliklerdeki işbirliğiyle artırılabileceğini öğrenmektedirler ${ }^{1}$.

Çocuğun yaşamının ilk yıllarında, "oyun gelişimin kaynağıdır ve yakınsak gelişim alanı yaratmaktadır" (Vygotsky, 1933-1967, s.16). Oyun, toplumsal kuralların kendini güçlü kılacak bir biçimde içselleştirilmesi için imgesel bir firsat sağlayarak, tümü oyun içerisinde ortaya çıkan ve oyunu okulöncesi gelişimin en yüksek düzeyine eriştiren "gönüllü amaçlar yaratma, gerçek-yaşam tasarılarını ve iradi güdüleri oluşturma" yeteneğinin gelişimine katkıda bulunmaktadır (Vygotsky, 1933-1967, s.16). Bu nedenle okulöncesi yıllarda, çocuğun sosyopsikolojik gelişiminin belirli bir evresi boyunca, yeni gelişimsel ilerlemelerin önemli bir kaynağı durumuna gelen bir etkinlik olan oyun, "öncü etkinlik" rolünü üstlenmektedir. Bu rol, oyunun okulöncesi çocuklar arasında en sık görülen etkinlik biçimi olduğunu ya da bu çocukların gelişimine katkıda bulunan tek şey olduğunu imâ etmemektedir; ancak oyun, mevcut psikolojik işlevlerin yeniden örgütlenmesini güçlendirecek olan büyük ilerlemelerin kaynağıdır:

Oyun sırasında çocuk her zaman ortalama yaşının üzerindedir, günlük davranışının üzerindedir; oyunda kendisinden sanki bir baş daha uzundur. Oyun, bir büyütecin odağındaki gibi, yoğunlaştırılmış bir biçimde bütün gelişimsel eğilimleri kapsamaktadır; oyunda çocuk sanki normal davranış düzeyinin üzerine sıçramaya çalışıyor gibidir (Vygotsky, 1933-1967, s.16).

Sonuç olarak oyun, kişinin dünyasını genişletme firsatı sağlamaktadır ve dolayısıyla Vygotsky, okulöncesi çocuk için oyunun bilişsel gelişim açısından yararlarını, daha ileriki yıllardaki başarılı bir eğitim boyunca ortaya çıkacak öğrenme ve gelişimin önemli bakımlardan bir prototipi olarak görmektedir.

Ayrıntılı olarak ele alındığında, özellikle bilişsel yeniden örgütlemenin önemli bir türü, oyun tarafından geliştirilmektedir. Vygotsky bunun, çocuğun, düşünüşünü ilk kez olarak kendisini çevreleyen en yakınındaki dışsal dünyanın sınırlamalarından özgürleştirebildiği ve dolayısıyla da düşüncesini tutarlı ve bağımsız bir biçimde örgütlemeye doğru ilk adımı attığ1 -mış gibi oyun gerçekleştirildiğini önesürmektedir. Oyun, çocuğun, anlam (sözcük) ile alg1, anlam ile nesne, ve anlam ile eylem arasında özgün nitelikteki sıkı birliği koparmasına yardımcı olmaktadır. Örneğin, bir

${ }^{1}$ Benim için bu bağlantılar, Weintraub'ı (1974) okuyarak açık bir hale gelmiştir. Bu makalede geliştirilmiş kuramsal tartışmalar için, büyük ölçüde bu kaynakta ve başka yerlerde ileri bir düzeyde geliştirilmiş olan Weintraub'ın düşüncelerine tețekkür borçluyum. 
yetişkin, çocuğa herhangi bir kelime söylediğinde, çocuk nesneyi bulmak için çevresine bakınır; hava güzel olduğu zaman çocuğa kötü havadan söz etmek zordur. Yine de -mış gibi oyun aracılığıyla, çocuk, anlam ve görüntü alanlarını birbirinden ayırdetmeye ve anlamların nesnel gösterenlerinden ayrıldığ 1 sürekli imgesel durumlar yaratmaya başlamaktadır. Sonuç olarak, oyun etkinliğinde, bir tahta parçası bebek yerine ya da bir çubuk, at yerine geçebilmektedir. -Mış gibi oyun bu bakımdan imgelemde, eylemlerin nesnelerden çok düşüncelerden doğduğu, anlamların baskın olduğu bir dünyanın yaratımını kapsamaktadır. Kısacası oyun, imgelem gelişiminin ilerlemesini sağlayarak "içselleştirilmiş" soyut düşünce biçimini hazırlamaktadır (Vygotsky, 1933-1967, El'konin, 1971).

\section{Vygotsky'nin Oyun Araştırmaları Üzerindeki Etkisi}

Vygotsky'nin düşünceleri oyun literatüründe nasıl bir yer tutmaktadır? En doğrudan ve sıkça sözü edilen etki, sembolik oyunda nesne ikame süreçlerinin gelişimi ile ilgili çalışmalarda yer almaktadır (örneğin, Fein, 1979, 1981; Rubin ve ark. 1983). Başlangiçta Vygotsky (1933/1967) ve sonraları El'konin (1971), "eksen" olarak kullanılan nesnenin rolü ve yerine kullanıldığı nesneye benzerliğinin değişmesi hakkında bazı iddialarda bulunmuşlardır. Birçok araştırmacı, bu denenceleri sınamış ve değerlendirmiştir. Ancak bu araştırmalarda incelenen konular Vygotsky'nin geniş tasarılarının kuramsal çerçevesi içerisine tam olarak yerleşmemiş durumdadır.

Vygotsky'nin çalışmalarına göndermede bulunan bir başka grup araştırma, yaratıcılık, problem çözme ya da hatta dil kazanımı gibi belirli bazı bilişsel yeteneklerle oyun arasındaki doğrudan ilişkileri araştırarak oyunun yararlarını değerlendirmeye çalışmıştır (bu literatürü kapsamlı bir şekilde gözden geçiren çalışmalar için bakınız, Rubin ve ark., 1983 ve Vandenberg, 1980). Bununla birlikte, Vygotky'nin düşünceleriyle ilgili daha önceki tartışmaların açıkça gösterdiği gibi, oyunun Vygotsky'nin varsaydığ 1 psikolojik yararları, belirli bazı psikolojik yeteneklerin hemen ve doğrudan artması değildir. Oyunun "yüksek psikolojik işlevler"le ilişkisi, karmaşık ve dolaylı biçimde değerlendirilmektedir. Oyun, gerçekleşmesi yıllar alabilen psikolojik işlevlerin yeniden örgütlenmesini özendiren uzun dönemli psikolojik süreçler için yalnızca hızlandırıcı bir güç sağlamaktadır. Dolayısıyla bu araştırmalar, Vygotsky'nin kavramlarından biriyle birleşirken, çaılşmalarının yüzeysel bir yorumunu içermekte ve daha öne açıklanan araştırma dizisiyle, Vygotsky'nin geniş kuramsal çerçevesinden kaynaklanan "esin"den bağımsız olarak sürüp gitmektedir.

Vygotsky'nin oyun araştırmaları üzerindeki en önemli etkisi daha dolaylı ve dağınıktır ve dolayısıyla bunları incelemeye yönelik alıntılar 
tarafindan tam olarak takdir edilememektedir. Vygotsky'nin en önemli etkisi, zihnin ve oyunun toplumsal biçimlenmesini vurgulayan araştırmacılar üzerinde olmuştur. Bu araştırmacıların çalışmaları, Vygotsky'den, bu vurgulamayı paylaşan diğer birçok kuramciyla (örneğin, Bateson, 1971; Huizinga, 1944-1955; Mead, 1934) birlikte yararlanma eğilimindedir. Bu gelenekten kaynaklanan araştırmaların büyük başarısı, kökeni yönünden temelde toplumsal bir etkinlik olan oyunun, öncelikle bakıcılarla bebekler arasında ve sonra da kardeşler ve çocuk grupları arasında gerçekleşen ilk etkileşimde yer aldığını göstermiş olmalarıdır. Başlangıçta, oyun ve kurallı oyunlar, bebekler etkin katılımcı rollerini üstlenmeye başlayıncaya kadar, önceleri her iki rolü de oynayan bakıcıların (ya da hatta işbirliği yapan büyük kardeşlerin) destekleyici rehberliği altında toplumsal bir bağlam içinde öğrenilmektedir. Bu kurallı oyunların, dilin ilk iletişimsel rolünün ortaya çıkmasında, sıraya girmenin gelişiminde, konuşma yoluyla anlaşmanın öğrenilmesinde ve diğer toplumsal becerilerin kazanılmasında önemli bir rol oynadığına ilişkin kanıtlar vardır (örneğin, Bruner, 1975, 1977; Cohen, 1987; Garvey, 1977; Kaye, 1982; Ratner ve Bruner, 1978; Ross ve Kay, 1980; Sachs, 1980).

Üstelik son araştırmalar bakıcıların desteğinin ve biçimlendirmesinin, bebeklik döneminin ötesine geçtiğine ve küçük çocukların -mış gibi etkinliklerine kadar uzadığına ilişkin kanıtlar sağlamıştır. Toplumsal rol oynama biçimlendirmesinin nasıl meydana geldiğiyle ilgili az sayıda çalışma ayrıntılı bir biçimde belgelenmiştir. $\mathrm{Bu}$ çalışmalar yararlı bir biçimde, yalnızca bakıcıların değil, akranların rolü üzerine de odaklanmış durumdadır (Dunn ve Dale, 1984; Miller ve Garvey, 1984). Ne yazık ki araştırmaların bu önemli bölümünde, rol oynama tek türü (anne-bebek rolüyle), rol oynamanın etkileri de etkileşimin fiziksel bağlamı ile sınırlandırılmıştır.

Akranlar arasındaki oyunla ilgili çalışmalarda, araştırmalar çocukların birlikte -mış gibi etkinlikleri gerçekleştirme biçimleri üzerine odaklanmıştır. Çocuklar toplumsal dünyalarının kaynaklarını kullanıyor ve özellikle üç büyük kategorideki öğelerin bazı kombinasyonlarına dayanıyor görünmektedirler: a) Katılımcılara verilen roller, b) eylem planları, öykü hatları ya da senaryolar c) Fiziksel nesneler ve ortamlar. En fazla ilgiyi ilk kategori toplamış olmakla birlikte, ikinci ve üçüncü kategoriler de bir parça ilgi çekmiştir. Ancak, araştırmalar, üç kategorinin de sembolik içeriğini ciddi bir şekilde değerlendirmeksizin bunların biçimsel ve yapısal özellikleri üzerine odaklanmış durumdadır.

İçerik dikkate alındığında, vurgu, her bir kategorinin zenginliği ya da bu üç kategorinin birbirleri üzerindeki olası etkileri üzerinde olmaktan çok, "tipik" 3, 4 ya da 5 yaşı betimleme üzerinde olmuştur (Curry, 1974; Curry ve Arnaud, 1984). Örneğin, az sayıda çalışma, değişik yaşlardaki çocukların oyun parçalarında üstendikleri rol türlerini incelemiş durumdadır; ancak 
gözlemlenen rollerin yalnızca çok azı, gerçekleştirilen ortak bir oyun parçasındaki katılımcılar arasında uyumu sağlayan temel anlamlarla ilişkilidir (planlar, senaryolar ya da öykünün hatları). Üstelik hem planlar, hem de senaryolar, biraz dikkat toplamış olmakla birlikte (Garvey ve Bendt, 1977; Nelson ve Seidman, 1984), bu araştırmalar, bunların içeriklerine ve dolayısıyla geldikleri daha büyük sosyokültürel dünya ile ilişkilerine değil, yine, zihinsel tasarımlar olarak bu olguların biçimsel psikolojik özelliklerine odaklanmışlardır.

Sonuç olarak, Vygotsky'nin kuramsal yaklaşımından etkilenen araştırmaların büyük bir bölümü, onun kuramsal yöneliminin doğasındaki en heyecan verici olanakların bütün üstünlüklerini kullanmak açısından başarısız olmuş durumdadır. Araştırmaların odağı, iki açıdan sınırlı olmuştur. İlk olarak, bu araştırmalar toplumsal dünyanın etkilerine, yalnızca doğrudan yüzyüze etkileşim bağlamında odaklanmaya çalışmışlardır. İkinci olarak, bu etkileşimlerin analizine ilişkin vurgulama, az sayıda istisnayla birlikte, hemen hemen tamamen katılımcılar arasındaki ortak anlamlarla gerçekleştirilen dilbilimsel amaçlar üzerinde olmuştur. Bu iki etmenin kombinasyonu, çalışmaları, araştırmanın yapıldığı süre boyunca yakalanabilecek doğrudan etkilerin araştırılmasıyla sınırlandırmıştır. Ancak Vygotsky'nin kendisinin de vurguladığ sıklıkla dolaylı, aracılı ve dağınıktır. Bunları yakalamak, zaman ve mekân bakımından, gerçek etkileşimden daha geniş bir yorumlayıcı çerçeveyi ve katılımcılar arasında mevcut etkileşim bağlamındaki konuşmalardan daha fazlasını dikkate alan bir yaklaşımı gerektirmektedir.

Bütün bu nedenlerden dolayı bu araştırmaların odağı, etkileşimin oluştuğu ve etkileşim boyunca gerçekleşen anlamların, imgelerin ve rollerin kaynaklandığı sosyokültürel çerçeve üzerinde olmaktan çok, özellikle bilișsel, dilbilimsel ya da toplumsal becerilerin aktarımı üzerinde olmuştur. Dolayısıyla, ironik bir biçimde, Piaget'in kuramında sosyokültürel boyutun bulunmaması, Vygotsky'nin etkisi için alan yaratmış olmasına karşın, şimdiye kadar yapılan araştırmalar sistematik bir biçimde oyun bağlamını tanımlayacak ve aydınlatacak geniş sosyokültürel öğelere kadar uzanmış durumda değildirler. (Biraz farklı bir bağlamda geliştirilmiş benzer bir tartışma için bakınız, Nicolopoulou ve Cole, baskıda.) Gelecek bölümde, bu tür konuları daha etkili olarak ele alabilecek bir araştırma perspektifinin bazı öğelerinin anahatlarını ortaya koyacağım.

\section{Oyunu Yeniden Ele Almak: Araştırmalar İçin Olası Bazı Yönler}

Oyunla ilgili psikolojik araştırmaları aydınlatmış olan iki temel kuramsal etkinin gözden geçirildiği önceki bölüm, en azından bazı araştırmacıların, oyunu yalnızca bireysel bir psikolojik etkinlik olarak gören 
düşünceden, toplumsal bir etkinlik olarak ele alan düşünceye doğru derece derece ilerlemiş olduklarını göstermektedir. Ancak bu araştırmacılar, oyun aracılığıyla ortaya konan kültürel anlamları olduğu gibi, oyunun içinde oluştuğu sosyokültürel çerçeveyi araştırmakta da yeteri kadar yol gidememişlerdir.

Bununla ilişkili zayıf bir nokta, alternatif bir şemanın tohumlarının Vygotsky'nin imgesel ortamın önemi üzerindeki 1srarında bulunabilecek olmasına karşın, temel olarak indirgemeci ve yararcı oyun görüşlerinin (genellikle birarada) benimsenmesi eğilimidir. Oyun hemen hemen hiçbir zaman, çocukların anlatımcı imgelemlerinin bir aracı olarak kendi koşulları içinde araştırılmamaktadır. Oyun, ya basit bir biçimde biliş, dil ya da iletişim gibi bazı başka yerleşmiş psikolojik işlevlerin bir yansıması olarak görülmektedir (benzer bir tartışma için, bakınız: Franklin, 1983), ya da oyun olmayan bazı başka etkinliklerin ortaya çıkmasındaki yalnızca nedensel rolüne dayanılarak, kendi içerisinde derinlemesine değerlendirilmeksizin araştırılmaktadır. Her iki yaklaşım da yararlı ve zaman zaman da uygun olmakla birlikte, oyun görüngüsünün tamamını kapsamamaktadır. Araştırmacılar, oyunu daha yerleşmiş psikolojik işlevlere dönüştürmekle ilgilendikleri için, aslında oyunu sıklıkla en ayırıcı yönlerini yakalamakta başarısız olarak kestirme yoldan incelemektedirler. Oyun, ayrıca birbiriyle ilişkili duygusal, zihinsel ve toplumsal yaşam alanlarından kaynaklanan ve bunları yansıtan imgesel etkinliğin bir anlatımı olarak kendi koşulları içinde de araştırılmalıdır.

Bu hedefi gerçekleştirmek için gerekli kaynakların birçoğu, özellikle bu yaklaşımların belirli öğelerine ilişkin anlayışımızı Durkheimcı ve Freudcu köklerine uzanarak zenginleştirmemiz durumunda Piagetci ve Vygotskyci perspektiflerin kendi içlerindeki geliştirilmemiş olanaklardan çıkartılabilir. Oyuna, bu görüşleri biraraya getirmek yoluyla, onu yalnızca etkileşimsel değil, kültürel ve imgesel bir etkinlik olarak da değerlendiren ve gerçek bir toplumsal etkinlik olarak saptayan bütüncül bir bakışaçısından bakabiliriz.

\section{Kuramsal Bir Çerçeve Gelişstirmeye Doğru}

$\mathrm{Bu}$ tür bir yaklaşım için kritik bir başlangıç noktası, Durkheim ile Vygotsky'nin yazıları ve Piaget'in ilk çalışmalarında ortaktır. Hem bireysel ruhsal yaşamın ve hem de toplumsal yaşamın tutarlılığı, kural sistemleri tarafindan yapılandırılmaktadır. $\mathrm{Bu}$ kural sistemlerinin altındaki temel yapılar, temel olarak, bireylerin kendilerine mal etmeleri ve içselleştirmeleri gereken "ortak bir değerlendirmenin sonucudur" (Durkheim, 1914-1973, s.151; ayrıca Weintraub, 1974'e bakınız -yakında çıkacak). Bu, dış sınırlamalar altında gerçekleştirilmiş eylemler için doğru olduğu gibi, özerk eylemler için de doğrudur. Özerklik, keyfi olarak hareket etmekle aynı şey değildir. Kendini denetleme ve kendi kendini yönetme yeteneğini gerektirmektedir (Vygotsky'nin [1933-1967] Piaget'le ilgili sözlerinin bir 
başka söyleyişi). Bağımsız düşünebilmek ve davranabilmek, belirli üstlerin yetkesine bağımlılıktan, paylaşılan ve gönüllü olarak kabul edilmiş kişisel olmayan kural sistemleri çerçevesinde davranmaya doğru ilerlemeyi gerektirmektedir. İnsanlar, bu yeteneği, işbirliği içeren toplumsal ilişkiler çerçevesi içinde davranarak kısmen geliştirirler. $\mathrm{Bu}$ tür etkinliğin gerektirdiği ve aynı zamanda insanların kavramasına yardımcı olduğu şey, kuralların bir üst tarafından aktarılmasının gerekmediği düşüncesidir. Kurallar, daha çok, etkinliğin kendi yapısının içinden gelebilirler ve katılımcılar tarafından değer verilen bir uygulamayı ya da etkinlik biçimini gerçekleştirebilmek için gereklidirler. Bu, uygulamanın kurallı bir oyun, etkin bir işbirliği ya da bir problemi çözmek için kavramsal matematik sistemlerinin kullanılması durumlarında da geçerlidir.

Dolayısıyla, Durkheim, Vygotsky ve Piaget'in paylaştıkları ve Vygotsky'nin defalarca vurguladığ 1 ve kendi tarzında geliştirdiği önerme, düşünme ve bilişsel gelişimin, gönüllü olarak kabul edilmesi zorunlu ortak kural sistemleri tarafindan kurulan sosyal etkinlik biçimlerine katılmayı kapsadığıdır. Giddens'in (1979) söylediklerini yeniden ifade edecek olursak, kural sistemleri yalnızca kısıtlayıcı değildirler, kısıtlayıcı ve aynı zamanda güçlü kılıcı olabilmektedirler. Kurallar, bütünleşmiş bir toplumsal grup bağlamında doğmaktadırlar ve bu bağlamda güçleri vardır. Durkheim'ın belirttiği gibi, toplumsal grubu hem düzenler, hem de bütünleştirirler, yani grubun birlikteliğini koruma hizmetinde bulunurlar.

Vygotsky'nin ayırıcı özelliklerinden biri, oyunu, bütün bu etkinliklerin önemli bir prototipi olarak görmesidir. Oyun zevk vericidir, içsel olarak gönüllüdür ve aynı zamanda da temel bir biçimde kurallı bir etkinliktir. (Oyunun hem gönüllü, hem kurallı; hem "serbest", hem katı bir biçimde düzenlenmiş olması gerekliliğinin yarattığ "ikiliğin" parlak bir sunumu için bakınız: Huizinga, 1944-1945). Oyunun iki temel öğesi, imgesel ortamın varlığ1 ve bu imgesel ortamdaki dolaylı kurallardır. Katılımcılar, oyundünyasının kurallarının (Huizinga'dan alınmış bir kavram) rehberliğinde, "gerçek" yaşamdan kendi zaman ve mekân sınırları içinde ilerleyen geçici bir etkinlik alanına doğru adım atarlar. Kural sistemleri, aslında oyun ortamının kendisinin kurulmasına hizmet etmektedir. Daha sonra bu kurallar güçlerini, çocuğun, oyun dünyasının paylaşılan etkinliklerinden elde ettiği zevkten ve bunlara olan bağlılığından almaktadırlar.

Sonuç olarak Vygotsky, oyunun, öğrenmede ve bilişsel gelişimde önemli bir role sahip olduğunu düşünmektedir. Çocuk, imgesel ortamı gerçekleştirmenin, ortamdaki dolaylı kurallara bağlılı̆̆ gerektirdiğini öğrenmektedir. Bu kabullenme gönüllü, ancak gereklidir. Kimse çocuklara bu kuralları kabul ettirmez, ancak çocuklar kurallara uymazlarsa oyun oynayamazlar. Üstelik oyun her zaman bir öğrenme etkinliğidir, çünkü öğrenmeyi, kuralları kavramayı, onların bir sistem oluşturduğunu görmeyi, 
onları inceleyerek biçimlendirmeyi ve oluşturdukları çeşitli alıştırma biçimlerinde ustalaşmayı gerektirmektedir. (Kurallı "alıştırmalar" düşüncesinin daha ileri bir değerlendirmesi için, bakınız: MacIntyre, 1984.) Görmüş olduğumuz gibi, basit bir -mış gibi oyun bile -örneğin küçük bir kızın anneymiş gibi yapması- anne rolünün içerisindeki normalde dolaylı olan kuralları açığa çıkarmayı ve bunlara dikkat etmeyi gerektirmektedir. Bu gerekliliklere, açık bir biçimde toplu olarak oynanan kurallı oyunlarda daha da güçlü bir şekilde uyulmaktadır.

Vygotsky'nin bu temaların gelişiminin derinlerine inerek verdiği bilgiler, Durkheim'dan Vygotsky'ye aktarılırken etkisi biraz azaltılmış olan pasajdaki düşünce kopleksindeki bir öğenin -Durkheim'ın, grup yaşamının, düzenlemelere dayandığı kadar bütünleşmeye de dayandığı üzerindeki ısrar1yeniden vurgulanmasıyla yararlı bir biçimde tamamlanabilir. Durkheim'ın bize verdiği bilgilere göre, kuralların işlevi katılımcıların davranışlarını düzenlemekle sınırlı olmak zorunda değildir. Ortak kurallar tarafından örgütlenmiş olan bir etkinliğe katılmanın çoğunlukla törensel bir öğesi de vardır. Bu öğe, bu ve başka biçimlerde, yalnızca katılımcıları düzenlemeye değil, grup kimliğini, birliğini ve bütünleşmesini pekiştirerek onları duygusal olarak birbirlerine bağlamaya da hizmet eder (Durkheim, 1912-1965). Bu süreçte, katılımcılar, grup tarafından gerçekleştirilen sembolik "ortak tasarımlamalar" evrenine giden bir yola ulaşırlar.

O halde bu bakışaçısı, oyun temalarının toplumdan kaynaklanan sosyokültürel anlamları temsil ettiği ve bu bakımdan grubun kimliğine ve karakterine katkıda bulunduğu düşüncesini ortaya koymaktadır. Katılımcıları duygusal olarak bağladıkları için, bunu kısmen oyun temaları gerçekleştirmektedir. Daha önce görmüş olduğumuz gibi, bunu gerçekleştirmelerinin bir yolu, katılımcıların dilek ve istekleri için imgesel bir doyum sağlamalarıdır. Bu bakımdan, hem Piaget'in hem de Vygotsky'nin Freud'dan almış oldukları ve izledikleri önerilerden bazılarına bütünüyle dönmek, Durkheim'a dayandırılabilecek kuramsal öğeleri güçlü bir biçimde tamamlayacak bir öğeyi ortaya koyabilir. Kısacası, oyunun sosyokültürel analizi, fantazi ve imgelemin oyun etkinliğindeki merkezi rolünü ihmal etmek yerine, bu rolü daha yakından değerlendirmelidir.

\section{Bazı Örnek Çabalar ve Uygulamaya Dönük Öneriler}

Burada önerilen sosyokültürel oyun yaklaşımının türü, geniş bir dizi olası alanı ve araştırma stratejisini çevrelemektedir. Bunları ayrıntılı olarak tartışmaktan çok, açıklayıcı bazı örnekler sunacağım.

Yorumlaylcı Analiz ve Kültürde Oyun Öğesi: Clifford Geertz: İlk örnek, özellikle çocukların oyunlarıyla ilgili olmak yerine, Huizinga'nın (19441955) "kültürde oyun öğesi" olarak adlandırdığı daha geniş bir konuyla ilgilidir. Daha önce sözü edilen konulardan birçoğunu biraya getiren dikkate 
değer bir çalışma, antropolog Clifford Geertz (1973) tarafindan yapılmış olan, Bali horoz dövüşünün "derin oyun" olarak ünlenmiş analizidir. Geertz, sanılabileceği gibi, gelişim psikolojisi için yol göstermede konuya uzak ya da güvenilir olmayan bir kaynak değildir; çünkü, yazılarından birinde de (1983, s.153) belirttiği gibi, tercih etmiş olduğu yorumlayıcı antropoloji bir tür "açık alan (outdoor) psikolojisi"ne ulaşmıştır.

Geertz, horoz dövüşünün Bali toplumunda kilit bir kültürel form olduğunu göstermektedir. Karmaşık bir bahis kuralları sistemi aracılığıyla, seyirciler de dövüşen horozların sahipleri kadar yoğun bir biçimde olayın içine girerler. Ancak para, merkezi konu değildir; bahse girmenin işlevi, daha çok, konunun can damarı olan horoz dövüşünün sembolik önemini artırmaktır. Horoz dövüşü, genellikle köyün en önde gelen erkeklerinin de içlerinde olduğu çeşitli katılımcılarıyla bir bütün olarak ele alındığında, Bali toplumunun bazı kilit özelliklerinin, özellikle statü düşmanlığı ve dayanışması örüntülerinin parlak bir sembolik tasarımlamasını ortaya koyar. Horoz dövüşü, bu süreçte, "denetimli" sembolik bir mekânda, normal olarak yüzeyin altında dikkatle tutulan kaygı verici ve gizil olarak patlayabilecek bir dizi duygunun ifadesini ortaya çıkarır. Dolayısıyla bu oyun biçimi, Bali toplumunun idealleri ve yapısı üzerine bir tür "toplumsalötesi" (metasocial) bir yorum sağlamaktadır: "Bir Balilinin Balili deneyimlerine anlam vermesi demek, kendi kendisine kendisi hakkında bir öykü anlatması demektir" (Geertz, 1973, s.448). Bununla birlikte bu oyun biçimi, düz bir tanımdan ya da içinde oluştuğu toplumun saf bir yansımasından daha fazla bir şeydir. Sembolik biçiminden dolayı, kesin olarak ciddi bir duygusal güce sahiptir. $\mathrm{Bu}$ toplumsal imge ve idealleri, özellikle parlak ve zorlayıcı bir biçimde ifade etmede ve dolayısıla bunları iletmede, yeniden üretmede ve pekiştirmede önemli bir rol oynamaktadır. Yani horoz dövüşü, kendisini biçimlendiren oldukça toplumsal bir gerçekliğin kurulmasına ve korunmasına yardım eden ortak bir öğrenme yaşantısı sağlamaktadır. Sonuçta, horoz dövüşü ne kadar "derin" olursa ya da oyuncuları duygusal olarak bağlayabilme ve duygularını harekete geçirebilme anlamında ne kadar fazla oyun içerirse, o kadar başarılı bir şekilde bilişsel etkilerini de gerçekleştirebilir.

$\mathrm{Bu}$ örneğin burada aktarılması, kuşkusuz, bütün oyunların tam olarak Bali horoz dövüşü gibi olduğunu ya da onunkine benzer toplumsal önemi bulunduğunu veyahut onunla eşit etkileri gerçekleştirdiğini imâ etme amacını taşımamaktadır. Ancak Geertz'in analizi, oyuna sosyokültürel olarak yönelen bir yaklaşımın ele alması gereken merkezi sorunlardan bazılarını çok kesin bir biçimde meydana çıkartmakta ve bu bakımdan en az üç kilit konuyu ifade etmektedir. İlk olarak, bu türden herhangi bir analizdeki kritik ilk adım, oyun biçimlerinin temsil ve ifade ettiği hem bireysel hem sosyokültürel anlamların yapılarını temel bir biçimde açıklama ve çözme 
anlamına gelen yorumlamadır. $\mathrm{Bu}$, yalnızca dikkati yüzeysel anlam üzerine toplamayı değil, bu anlamları örgütleyen belirli daha derin örüntüleri yeniden yapılandırmayı da kapsamaktadır. İkinci olarak, oyun, sonuçta katılımcılar üzerinde güçlü bir duygusal etkisi olabilecek önemli bir öğesi bulunan sembolik bir eylem biçimidir. Üçüncü olarak da, oyun, bilişsel amaçları gerçekleştirmek için duyguları harekete geçirebilir. Aslında, Geertz, bu son öğeyi oyunun "derin" biçimlerinin belirleyici özelliği olarak görmektedir.

Geertz'in giriştiği bu analiz türünün, egzotik yöreler ya da yabanc1 kültürlerle sınırlı tutulması gerekmez. Yöneldiği ilgi alanları, çocukların oyunlarına ilişkin araştırmalara aydınlatıcı bir şekilde uygulanabilir. Bunlar, örneğin, çocukların oyunlarının bilişsel ve duygusal boyutlarının karmaşık etkileşimini, oyun biçimlerinde anlatım bulan kültürel öğelerin doğasını ve çekiciliğini, ve çocukların gelişimlerini etkileyen ve onlara toplumsal kimlik ve bağlılıklarını biçimlendirmede kendilerine yardımcı olan oyun etkinliklerine katılma şekillerini anlamamıza yardım edebilir.

"Açık Alan Psikolojisi" nin Canlandırllması: Vivian Paley

Çocukların oyunlarının analizine bu tür bir yaklaşımı getiren bir grup araştırma, Vivian Paley'in (örneğin, 1981, 1984, 1986, 1988) okulöncesi sınıflarında gerçekleştirdiği bir dizi zengin etnografik araştırmadır. Paley, bu makalede vurgulanan kuramsal sorun türlerini doğrudan bir biçimde nadiren değerlendirdiği halde, bunlara sezgisel olarak dikkatle yaklaşmaktadır aslında, Paley'in araştırmaları kuramsal olarak oldukça ince ve karmaşıktır-. Paley'in yaklaşımının kuramsal temellerinin gösterişli olmadığı gerçeği, raporlarının, zaman zaman yanıltıcı bir biçimde basitmiş gibi görünmesine yol açtığı kadar, kitaplarını daha akılda kalıcı ve çok ilginç kılmaya da şüphesiz yardımcı olmaktadır. Diğer yandan, kuramsal sorunlarla doğrudan bağlantı kurmaktan kaçınması, onu, bu sorunları bütünüyle izlemekten alıkoymuş olabilir.

Paley, değişik kitaplarında sosyokültürel bir etkinlik olarak oyunun çeşitli yönlerini vurgulamakta ve oyunun çocukların dünyayı kavramalarının gelişimindeki (cinsiyet kimliği de dahil olmak üzere) kimliklerinin biçimlenmesindeki ve toplumsal yaşamın değişik alanlarına girişlerindeki rolünü araştırmaktadır. Çocukların zihinsel gelişimlerini olduğu gibi ahlâksal ve duygusal gelişimlerini de, tutarlı bir biçimde grup yaşamı bağlamına yerleştirmekte ve farklı oyun biçimlerinin bu sosyokültürel bağlama hem nasıl bağlı olduklarını, hem de bu bağlamın kurulmasına nasıl yardımcı olduklarını göstermektedir.

Örneğin, Paley'in Mollie Üç Yaşında adlı kitabı, fantazi oyun ile ahlâk eğitimi arasındaki yakın ve karmaşık ilişkiyi değerlendirmektedir. Fantazi oyun, çocuklar için, korkularını, isteklerini ve duygusal açıdan yüklü önemli 
endişelerini keşfetmekte kullandıkları bir kendini ifade etme biçimidir. Ancak, aynı zamanda da, yalnızca ortak ve gönüllü olarak kabul edilmiş kural ve anlam sistemleri bağlamında başarılı bir biçimde yer alabilen kurallı bir etkinliktir. Çocuklar, oyun dünyasının sembolik mekânının oluşabilmesi için, bir önkoşul olarak sınıfta ahlâksal bir düzeninin gerekli olduğunu öğrenirler. Paley, bu düzenin kurulduğu ve korunduğu süreçleri izlemektedir. Paley'in belirttiği gibi, "özel fantazileri toplumsal oyuna, toplumsal oyunu çocukların ve öğretmenlerin kurallı toplumuna dönüştüren mantığı bulmaya" gereksinmemiz vardır (Paley, 1986, s.17). Üstelik, küçük oyun dünyas1 evreni, çocukların araştırabildikleri, ustalaşma girişiminde bulundukları ve geniş toplumsal dünyanın gizlerini keşfettikleri bir "deneysel tiyatro" (s.xv) olarak hizmet etmektedir. Dolayısıyla Paley, çocukların fantazi oyununun, kendilerini ifade ettikleri ve zevk aldıkları bir etkinlik olduğunu ortaya koymaktadır; ancak, bu aynı zamanda oldukça kritik bir biçimde öğrenme ve araştırma sürecidir -birkaç biçimde "gerçekliğe götüren bir yol"dur (s.xv).

Kısacası, Paley'in analizi, çocukların oyunlarına, oyunun hem sembolik hem kurallı karakteriyle ilgilenerek ve oyunun bilişsel, duygusal ve sosyokültürel boyutları arasındaki etkileşime önem vererek yaklaşmanın değerini dikkat çekici bir şekilde ortaya koymaktadır. Paley, kitaplarında, biraz daha ilgilenilmesi, düzeltilmesi ve geliştirilmesi gereken bir dizi heyecan verici araştırma konusuyla ilgili firsatları ortaya koymaktadır.

"Gerçekliğe Götüren Bir Yol" Olarak Fantazi Oyunu: Çocukların Öyküleri ve Imgelemleri: Burada, öncülüğü Paley tarafından yapılan ve genişletebileceğimiz nitelikteki gelecek vaadeden bir tekniği anlatacağım. Paley'in sınıflarında başlattığı etkinliklerden biri, çocukların anlattıkları öyküleri öğretmene ya da bir başka yetişkine yazdırtmalarını içermektedir. Her bir günün sonunda, seçilen çocuk/yazar ile diğer çocuklar öyküyü canlandırırken, gün boyunca yazdırılan öyküler aynı ögretmen tarafindan bütün gruba yüksek sesle okunmaktadır. Bu öykü canlandırma uygulaması, (başka şeylerle birlikte) çocukların, diğerlerinin öykülerini dinlemelerini ve hatta bunlara etkin olarak katılmalarını sağlayarak iletişimi ve çocuk grubu içerisindeki yaygın kültürün gelişimini hızlandırmayı amaçlamaktadır.

Son zamanlarda, 4 yaş çocuklarından oluşan bir sınıftan bir yıl boyunca bu yolla edinilmiş ve kendiliğinden yazılmış bir öykü koleksiyonunun analizini kapsayan bir araştırma projesiyle uğraşıyorum (Nicolopoulou ve Scales, 1990; Nicolopoulou, Scales ve Weintraub, baskıda). Araştırma, toplumsal ve sembolik imgelemdeki cinsiyet farklılıkları çocuklar tarafından yazılan öykülerde sergilendiği için, bu farklılıkların ortaya çıkışına odaklanmaktadır. Araştırma, çocukların öykülerinin -fantazi oyunda ortaya koydukları diğer senaryolar gibi- dikkatli bir biçimde analiz edildiklerinde, çocukların dünyaya, özellikle de toplumsal ilişkilere bakış biçimleri hakkında bazı şeyleri göz önüne serebilen anlamlı metinler olduğu sayıltısını 
başlangıç noktası olarak almaktadır. Çocuklar, öyküleri oluştururken, sıklıkla, farkında olmadıkları biçimlerde algılarını şekillendiren, kendileri için kültürel bakımdan mevcut olan imgelerden ve sembolik çerçevelerden yararlanırlar. Aynı zamanda, çocuklar bu kültürel öğeleri kendi amaçları için kullanırlar ve manipüle ederler ve onların bunu nasıl yaptıklarını izlememiz gerekmektedir. Aynı noktayı başka bir biçimde ele alırsak, bir öykü anlatmak ve onu oynamak sembolik, ve bu durumda da başkalarıyla birlikte ortaya konan -kolektif- bir eylem biçimidir. Çocuklar dünyayı, kendileri ve başkaları için temsil etmek ve anlamlandırmak için başka sembolik ifade biçimlerini kullanırlar. Aynı zamanda, öyküleri, kafalarını meşgul eden duygusal açıdan önemli belirli temaları ifade etme ve altta yatan bu temalarla sembolik olarak baş etme ya da bunları çözme yolu olarak kullanmaktadırlar.

Dolayısıyla, araştırmam, çocukların dünyayı anlama ve temsil etmeye yönelik sembolik yapıların farklı kullanım biçimlerine ve özellikle bu farklılıkların cinsiyet tarafindan yapılandırılma yollarına odaklanmaktadır. Sonuç olarak, bu analiz, çok erken yaşlarda bile kız ve erkek çocukların, dünyayı ve özellikle de toplumsal ilişkiler dünyasını birbirinden kesin olarak farklı yollarla kavradıklarını ve tasarımladıklarını önesürmektedir. $\mathrm{Bu}$ farklılıkları yakalamanın, erkeklerde ve kadınlarda gelişimsel olarak farklı bilişsel ve kültürel tarzların ortaya çıkmasını anlamamıza yardım edebileceğine inanmaktayım. Öyküler her gün bütün grupla paylaşılmasına karşın, erkekler ve kızlar farklı tarzda öyküler anlatmışlardır. Kızlarla erkeklerin öyküleri, yalnızca konu içeriği bakımından değil, aynı zamanda kullandıkları anlatım yapısı ve estetik imgelemin bütünü açısından da sistematik ve tutarlı biçimde farklılaşmıştır. Çok şematik olarak özetlenirse, kızların öyküleri düzenlilik, erkeklerin öyküleri ise düzensizlik eğilimi göstermektedir ve bu fark, hem içerikte hem de biçimde görülmektedir.

Oyun Dünyası ve İşbirliğiyle Öğrenme Kültürü: Son olarak, sürmekte olan diğer bir araştırma dizisi (Nicolopoulou ve Cole, baskıda), sosyokültürel bir oyun yaklaşımının çocukların öğrenmesini ve bilişsel gelişimini ilerletmedeki olası rolünü aydınlatmaya gerçekten yardım edebilir. Bu çalışmanın konusu, San Diego California Üniversitesi'ndeki Karşılaştırmalı İnsan Bilişi Laboratuvarı'nın (Laboratory of Comparative Human Cognition - LCHC) ilkokul çocukları için uzun dönemli bir projesi olan okul-sonrası bir eğitim programına -"Beşinci Boyut"a- katılan çocukların öğrenme yaşantılarının niteliğidir. Bilgisayar oyunlarının ve bilgisayarla ilgili diğer materyallerin yaygın bir biçimde kullanımını gerçekleştiren bu program, oyunun ve imgelemin büyük bir rolünün olduğu işbirliğiyle öğrenmeye dayalı güçlü eğitsel etkinlik sistemleri yaratacak yöntemleri bulmayı amaçlamaktadır.

Güçlü bir Vygotskyci esin kaynağına sahip olan programın ardındaki kuramsal mantık, oyun öğesinin geniş eğitsel uygulama sistemleriyle etkili 
bir biçimde bütünleştirilebilme yollarını bulma çabasını vurgulamaktadır. Beşinci Boyut'un kendi içinde oyunlar ve etkinlikler, işlevi, ayrı bir oyun dünyası yaratmak olan karmaşı bir sistemde örgütlenmektedir. Dolayısıyla Beşinci Boyut, belirli bir iç mantığı olan temel bir etkinlik sistemi olarak görülebilir. Hedef, işbirliğiyle öğrenmeyi destekleyebilecek ve çocukların, basit bir biçimde başka insanlardan bilgi almak yerine, etkin bir biçimde kendi gelişimleri doğrultusunda hareket etmelerini sağlamak için kendi kendilerine adım adım ilerlemeye güdülendikleri bir bağlamı yaratmaktır. $\mathrm{Bu}$, kesin bir biçimde, çocukların kendi eğitimlerinde etkin bir rol almalarına izin verildiği ve bunun için yüreklendirildikleri ortak kurallar sisteminin kavranması ve kabulü aracılığılla olmaktadır.

Beşinci Boyut programının sürmekte olan geniş değerlendirmesinin bir parçası olan araştırmamız, bu ilkelerin uygulamada nasıl işlediği sorunuyla ilgilenmektedir. Özellikle de, bunların en başarılı bir biçimde hangi koşullarda işlediklerini belirlemeyi ve analiz etmeyi amaçlamaktayız. $\mathrm{Bu}$ probleme, programın içinde bulunduğu iki Beşinci Boyut bölgesinin içinde yer alan kurumsal ortamların karşılaştırmalı analizini yaparak yaklaşmaktayız. Bu süreçte, sürmekte olan ortak etkinlik sistemlerinin içine ayrılmaz bir şekilde yerleşmiş olan bilgi yaratımına ve aktarımına gerçekten ortak bir biçimde yaklaşmamızı sağlayabilecek bir yöntemi önermekteyiz. Yeni bir etkili formülasyonu kullanmak için, "toplumsal olarak yerleştirilmiş biliş" (Lave, 1988) dinamiklerini araştırmaktayız. Daha genel bir biçimde, birçok psikolojik araştırmada sözkonusu olan kavramlardan çok, daha kapsamlı olan düşüncenin toplumsal gömülmüşlügü (embeddedness) ve bireysel gelişim kavramından yararlanmaya çalıştık. Dolayısıyla, birbiriyle bağlantılı iki yolla daha bütüncül bir sosyokültürel yaklaşım yönünde harekete geçtik: a) Belirli etkileşimleri, gerçekten ortak bir gerçeklik olarak görülen kültürel ve kurumsal bir bağlama yerleştirmek; dolayısıyla, daha önce belirtildiği gibi Vygotsky'nin esin verdiği birçok araştırmada dolaylı olarak bulunan etkileşimsel indirgemecilikten kaçınmak, b) öncelikle kuşakları ve ortak bilginin yayılımını izleyerek işbirliğiyle öğrenmeyi gerçekçi bir şekilde araştırmak için bir yol bulmak.

Temel analiz birimi olarak, sürekli bir ortak etkinlik sistemi olduğu düşünülen ve geniş bir dizi olası başarı düzeyi sunan belirli bir bilgisayar oyununu almaktayız. İlerleme; deneme ve yanılmayı, epeyce düşünme ve çabayı ve genellikle etkili bir işbirliğini ve daha önceden elde edilmiş bilgilerin paylaşılmasını gerektirmektedir. İşlem örüntülerini ve bir yıllık kursun sonunda iki bölgedeki bilişsel sonuçları izlemekteyiz. Sonuçlarımız, oyunun bir bölgede diğerinden daha başarılı bir biçimde "çalıştığını"; çocukların bireysel olarak daha iyi olmalarının yanısıra bir bütün olarak grubun daha hızlı ilerlediğini ve daha başarılı olduğunu göstermektedir (her iki bölgeden katılımcılar arasında da ciddi ölçüde bireysel ayrılmalar 
olmasına karşın). İki bölgenin şaşırtıcı derecedeki farklı sonuçları, araştırabildiğimiz kadarıyla, çocukların geçmişlerine ilişkin özellikleriyle açıklanamamaktadır; çünkü iki grup da bu yönden dikkatli bir şekilde denkleştirilmiştir. Temel sonucumuz, bilişsel başarı derecesinin, her iki bölgedeki grupların bir bütün olarak ortak karakterine -işbirliğiyle öğrenme kültürü olarak adlandırdığımız şeyin güçlülüğü ya da zayıflığına- bağlı olduğudur. Bu özellik, birbirini karşılıklı olarak pekiştiren iki öğeye dayanarak gösterilmektedir: a) Çocukların kendi aralarındaki ve çocuklarla yetişkinler arasındaki etkileşim örüntülerinin, özellikle problem çözme etkileşiminin yoğunluğu ve niteliği, b) Beşinci Boyut'un oyun dünyasına ve onun kural sistemlerine bağl1lık ve dahil olma dereceleri. Bu öğeler, bundan başka Durkheim'ı (1897-1951; 1925-1973) izleyerek, oyun dünyasının toplumsal grubun bütünleşmesi ve düzenlenmesiyle oluşturulan toplumsal bağlılık/birleşmişlik derecesi olarak adlandırdığımız olguyla anlaşılmaktadır. Toplumsal bağlılık, bölgelerden birinde dikkati çekecek ölçüde daha güçlüdür ve bu farklılığın sonuçlarından biri yüksek bilişsel başarıdır.

$\mathrm{Bu}$ bulgular, bireysel gelişimin gerçekleștiği toplumsal ya da bireylerarası (interpsychological) bağlamın, en yakın çevredeki ikili etkileşimler ya da küçük grup etkileşimleri çerçevesiyle sınırlı olarak görülmemesi gerektiğini, bu bağlamın, bu etkileşimlerin anlamını ve etkisini oluşturan daha geniş sosyokültürel çerçevenin bütününü de kapsadığı iddiasını desteklemektedir. Bu örnekte, her bir bölgedeki belirli etkinlikler ve etkileşimler, o bölgenin kültürünün şekillendirdiği bağlama gömülmüş ve o bağlam tarafından oluşturulmuştur. Dolayısıyla, ortak bir gerçeklik -bir etkinlik sistemi- olarak görülen bölge kültürü, ve belirli bir etkinliğe bağlı birbirinden farklı bilgi yayma ve toplama örüntülerini değerlendirmede kilit bir etmen durumundadır. Aynı etkinlik görevi, iki farklı sosyokültürel farklı bir şekilde gelişmekte ve farklı anlamlarla doldurulur duruma gelmektedir.

\section{Bir Sonuç ve Bir Bașlangıç}

Bu makalede oyunu, yalnızca etkileşimsel bir etkinlik olarak değil, aynı zamanda kültürel ve imgesel yönleri de bulunan toplumsal bir etkinlik olarak

etkili bir biçimde ele alabilecek bir yaklaşımı ve bu yaklaşımın bazı kilit özelliklerinin anahatlarını tartışmış bulunuyorum. Böyle bir yaklaşım, oyunun zihnin oluşumundaki, benliğin biçimlenmesindeki, kültürün tanımlanması ve yeniden üretilmesindeki rolü ile ilgili konuların araştırılmasına yardımcı olabilir. Bu yaklaşım, gerçekten de, bu araştırma alanlarının birbiriyle yakından ilgili olduğunun kabul edilmesini gerektirmektedir.

Sosyokültürel oyun görüşünü gelişim psikolojisiyle daha gerçekçi bir biçimde bütünleştirmek, araştırmalar açısından, burada yalnızca birkaç örneğini sunduğum birçok heyecan verici olanak ve düzenleme için bir başlangıç oluşturmaktadır. Üstelik bu yaklaşım, vurgulamış olduklarımdan 
başka bir dizi potansiyel olumluluğu da meydana çıkarmaktadır. İlk olarak, bu yaklaşım, oyunu bazı soyut parçalarını ortaya çıkarmak amacıyla parçalamaktan çok, onun "doğal ortamı"nda oluştuğu biçimiyle bütün bir tablosunu elde etmemize yardımcı olan bir yaklaşımdır. Bu yaklaşım, gündelik ortamlarında gözlemleyebilecekleri oyun etkinliklerine uygulanabileceği için, sonuç olarak uygulamacılara benzer ve tanıdık geliyor olmalıdır. İkinci olarak, birçok psikologun yadsıdığı bir gerçeği, -hatta, kimileri yalnızca çocukların oynadığını önesürmüşlerdir!- çocuklarla yetişkinlerin oyunları arasındaki temel sürekliliği meydana çıkarmaktadır. Üçüncü olarak, bu yaklaşım, doğrudan ya da dolaylı biçimde oyuna yönelik zengin ve kapsamlı pek çok araştırma yürütmüş olan sosyolog, antropolog ve kültür tarihçileri ile (örneğin, Ariés, 1960-1962; Caillois, 1958-1961; Connerton, 1989; Corsaro, 1985; Fine, 1985, 1987; Huizinga, 1944-1955; Rizzo, 1989; Schwartzman, 1978, 1980; Turner, 1967, 1969, 1986) güçlerimizi birleştirmemize firsat sağlamaktadır.

Yine de, böyle bir disiplinlerarası işbirliği ve karşılıklı verimlilik süreci, dağınık bir eklektizm içerisinde değil, üzerinde düşünülmüss bir sentez ruhu içerisinde gelişmelidir. Gelişim psikologlarının, oyunun sosyokültürel boyutlarını etkili bir şekilde ele alan kuramsal açıdan tutarlı bir oyun yaklaşımını geliştirinceye kadar 'ecumenicism'in yararlarını ortadan kaldırma ve gizli tehlikelerinden kaçınma olasılıkları bulunacaktır. Bunu yapmak, önemli yönlerden, Piaget ve Vygotsky'nin ve onlardan kaynaklanan araştırma geleneklerinin ötesine doğru hareket etmemizi gerektirmektedir. Ancak bir kere daha vurgulanmalıdır ki, bu proje, Piaget ve Vygotsky'ye dayanmaktadır ve bu araştırmacıların görüşlerinden ayrılmak ve vazgeçmek yerine, bunların genişletilmesini kapsamaktadır.Vygotsky'nin, oyunu toplumsal bir etkinlik olarak ele alışı, Piaget'inkinden daha derinlemesine ve daha gelişkin olmasına karşın, Piaget'in yaklaşımı, herhangi bir sosyokültürel analiz için önerilecek önemli yönlere sahiptir. Hem Piaget hem Vygotsky, analizlerini bu noktaya vardırmamış olsalar da, örneğin oyundaki duygusal öğe ve bu öğenin oyunun bilişsel değerine katkısı konusunda farkındalığa sahiptirler. Ancak bu düşünürlerden etkilenen araştırmacılar, kendi taslak ya da tamamlanmamış önerilerini geliştirmektense, analiz odaklarını daha da daraltma eğiliminde olmuşlardır. Daha kapsamlı ve aydınlatıcı bir yaklaşımı oluşturmak için gerekli kilit konumundaki kavramsal kaynaklardan birçoğu, Piagetci ve Vygotskyci perspektiflerin kendi içlerindeki geliştirilmemiş öğelerden -özellikle bu öğeleri ele alış biçimimizi, bunların Durkheim ve Freud'daki köklerine dayandırarak derinleştirirsek- yararlanabilirler.

Burada yinelemiş olduğum bu dört kuramcının çalışmalarında bulunabilecek birbiriyle bağlantılı kavram ve ilgi alanları ağı, oyun ve gelişimdeki rolüne ilişkin ilerideki araştırmalara yol gösterebilen ve bunları 
biraraya getirebilen ilgili bir kuramsal çerçeve için vazgeçilemez bir dayanak sunmaktadır. Şimdi görevimiz, bu kuramsal çerçeveyi, yaratıcı bir biçimde genişletmek ve hem araştırmadaki hem uygulamadaki gelişimsel sorunlara doğru yönlendirmek için geliştirmek ve derinleştirmektir.

\section{KAYNAKÇA}

Ariés, P. (1962). Centuries of childhood: A social history of family life. New York: Vintage. (Originally published in French in 1960).

Bates, E., Benigni, L., Bretherton, I., Camaioni, L. \& Volterra, J. (1977). From gesture to first world: On cognitive and social prerequisites. In M. Lewis \& L. A. Rosenblum (Eds.), Interaction, conversation, and the development of language. New York: Wiley.

Bateson, G. (1971). The message 'This is play.' In R. E. Herron \& B. Sutton-Smith (Eds.), Child's play (pp. 261-266). New York: Wiley.

Bruner, J. S. (1975). The ontogenesis of speech acts. Journal of Child Language, 2, 1-19.

Bruner, J. S. (1975). Early social interaction and language acquisition. In H. R. Schaffer (Ed.), Studies in mother-infant interaction. London: Academy Press.

Bruner, J. S. (1986). Actual minds, possible worlds. Cambridge, MA: Harvard University Press.

Caillois, R. (1961). Man, play, and games. New York: Free Press. (Originally published in French in 1958).

Cohen, D. (1987). The development of play. New York: New York University Press.

Connerton, P. (1989). How societies remember. Cambridge: Cambridge University Press.

Corsaro, W. (1985). Friendship and peer culture in early years. Norwood, NJ: Ablex.

Curry, N. E. (1974). Dramatic play as a curricular tool. In D. Sponsellor (Ed.), Play as a learning medium. Washington, DC: NAEYC.

Curry, N. E. \& Arnaud, S. (1984). Play in preschool settings. In T. Yawkey \& A. Pellegrini (Eds.), Child's play: Development and applied (pp. 273-290). Hillsdale, NJ: Erlbaum.

Dunn, J. \& Dale, N. (1984). I a daddy: 2-year-olds' collaboration in joint pretend with sibling and with mother. In I. Bretherton (Ed.), Symbolic 
play: The development of social understanding (pp. 131-158). New York: Academic Press.

Durkheim, E. (1965). The elementary forms of the religious life. New York: Free Press. (Originally published in French in 1912).

Durkheim, E. (1973). The dualism of human nature and its social conditions. In R. N. Bellah (Ed.), Emile Durkheim on morality and society (pp. 149-163). Chicago: University of Chicago Press. (Originally published in French in 1914).

Durkheim, E. (1973). Moral education. New York: Free Press. (Originally published in French in 1925).

El'konin, D. (1971). Symbolics and its functions in the play of children. In R. E. Herron \& B. Sutton-Smith (Eds.), Child's play (pp. 221-230). New York: Wiley.

Fein, G. G. (1975). A transformational analysiss of pretending. Developmental Psychology, 11, 291-296.

Fein, G. G. (1979). Play and acquisition of symbols. In L. Katz (Ed.) Current topics in early childhood education. Norwood, NJ: Ablex.

Fein, G. G. (1981). Pretend play: An integrative review. Child Development, 52, 1095-1118.

Fein, G. G., \& Apfel, N. (1979). The development of play: Style, structure, and situation. Genetic Psychology Monographs, 99, 231-250.

Fein, G. G., \& Moorin, E. R. (1985). Symbols, motives and the words. In K. Nelson (Ed.), Children's language(Vol. 5), New York: Gardner Press.

Fein, G. G., \& Robertson, A. R. (1975). Cognitive and social dimension of pretending in two-year-olds. Detroit: Merril-Plamer Institute. (ERIC Document Reproduction Service No. ED 119 806).

Fenson, L. Kagan, J., Kearsley, R. B., \& Zelazo, P. R. (1976). The developmental progression of manipulative play in the first two years. Child Development, 47, 232-235.

Fenson, L., \& Ramsay, D. (1980). Decentration and integration of the child's play in the second year. Child Development, 51, 171-178.

Fine, G. A. (Ed.) (1985). Meaningful play: playful meanings. Champaign, IL: Human Kinetics.

Fine, G., A. (1987). With the boys: Little league baseball and preadolescent culture. Chicago: University of Chicago Press. 
Franklin, M. B. (1983). Play as the creation of imaginary situations: The role of language. In S. Wapner \& B. Kaplan (Eds.), Toward a holistic developmental psychology (pp. 197-220). Hillsdale, NJ: Erlbaum.

Garvey, C. (1977). Play. Cambridge, MA: Harvard University Press.

Garvey, C., \& Bendt, R. (1977). Organization of pretend play. Paper presented at the annual meeting of the American Psychological Association, Chicago.

Geertz, C. (1973). The interpretation of cultures. New York: Basic Books.

Geertz, C. (1983). The way we think now: Toward an ethnography of modern thought. In Local knowledge. Further essays in interpretive anthropology (pp. 147-163). New York: Basic Books.

Giddens, A. (1979). Central problems in social theory: Action, structure and contradiction in social analysis. Berkeley: University of California Press.

Huizinga, J. (1955). Homo ludens: A study of the play element in culture. Boston: Beacon Press. (Originally published in German in 1944).

Inhelder, B., Lezine, I., Sinclair, H., \& Stambak, M. (1972). Les débuts de la fonction symbolique [Origins of the symbolic function]. Archives de Psychologie, 41, 187-243.

Jackowitz, E. R., \& Watson, M. W. (1980). The developmnet of object transformations in early pretend play. Developmental Psychology, 16, 543-549.

Kagan, J., Kearsley, R. B., \& Zelazo, P. R. (1978). Infancy: Its place in human development.Cambridge, MA: Harvard University Press.

Kaye, K. (1982). The mental and social life of babies. Chicago: University of Chicago Press.

Kessen, W. \& Fein, G. G. (1975). Variations in home-based infancy education. Final report to the Office of Child Development. HEW (ERIC Document No. ED 118 233).

Lave, J. (1988). Cognition ,n practice: Mind, Mathematics and culture in everyday life. Cambridge: Cambridge University Press.

Leontiev, A. N. (1981). Problems of the development of the mind. Moscow: Progress Publishers. (Originally published in Russian in 1959).

Lowe, M. (1975). Trends in the development of representational play in infants from one to three years -An observational study. Journal of Child Psychology and Psychiatry, 16, 33-47. 
MAcIntyre, A. (1984). After virtue. Notre Dame, IN: University of Notre Dame Press.

Mead, G. H. (1934). Mind, self, and society. Chicago: University of Chicago Press.

Miller, P., \& Garvey, C. (1984). Mother-baby role play: Its origin in social support. In I. Bretherton (Ed.), Symbolic play : The development of social understanding (pp.101-130). New York: Academic Press.

Mussen, P. H. (Series ed.) \& Hetherington, E. M. (Vol. Ed.) (1983). Handbook of child psychology: Vol 4. Socialization, personality, and social development. New York: Wiley.

Nelson, K. \& Seidman, S. (1984). Playing with scripts. In I. Bretherton (Ed.), Symbolic play: The development of social understanding (pp. 4571). New York: Academic Press.

Nicolich, L. (1977). Beyond senserimotor intelligence: Assessment of symbolic maturity through analysis of pretend play. Merrill-Palmer Quarterly, 23, 89-99.

Nicolopoulou, A. \& Cole, M. (in press). The generation and transmission of shared knowledge in the culture of collaborative learning: The Fifth Dimension, its play world, and its institutional contexts. In E. A. Forman, N. Mİnick, \& C. A. Stone (Eds.), Contexts for learning: Sociocultural dynamics in children's development. New York: Oxford University Press.

Nicolopoulou, A. \& Scales, B. (1990). Gender differences and aesthetic imagination in the stories of four-year-olds: 'Socialist realism' versus 'grotesque surrealism.' Paper presented at the $17^{\text {th }}$ Annual Conference of the International Children's Literature Association. San Diego, CA

.Nicolopoulou, A., Scales, B. \& Weintraub, J. (in press). Gender differences and symbolic imagination in the stories of four-year-olds. In A. H. Dyson \& C. genishi (Eds.), The need for story: Cultural diversity in classroom and community. Urbana, IL: NCTE.

Paley, V. (1981). Wally's stories. Cambridge, MA: Harvard University Press.

Paley, V. (1984). Mollie is three: Growing up in school. Chicago: University of Chicago Press.

Paley, V. (1986). Boys and girls: Superheroes in the doll corner. Chicago: University of Chicago Press.

Paley, V. (1988). Bad guys don't have birthdays. Chicago: University of Chicago Press. 
Piaget, J. (1962). Play, dreams and imitation in childhood. New York: Norton. (Originally published in French in 1945).

Piaget, J. (1965). The moral judgmentof the child. New York: Free Press. (Originally published in French in 1932).

Ratner, N., \& Bruner, J. S. (1978). Games, social exchange, and the acquisition of language. Journal of Child Language, 5, 391-402.

Rizzo, T. (1989). Friendship development among children in school. Norwood, NJ: Ablex.

Rogoff, B., \& Wertsch, J. V. (1984). Editors' notes. In B. Rogoff \& J. V. Wertsch (Eds.), Children's learning in the zone of proximal development. San Francisco: Jossey-Bass.

Rosenblatt, D. (1977). Developmental trends in infant play. In B. Tizard \& D. Harvey (Eds.), The biology of play. Philadelphia: Lippincott.

Ross, H. S., \& Kay, D. A: (1980). Theorigins of social games. In K. H. Rubin (Ed.), Children's play (pp. 17-31). San Francisco: Jossey-Bass.

Rubin, K. H. (1980). Fantasy play: Its role in the development of social skills and social cognition. In K. H. Rubin (Ed.), Children's play (pp. 69-84). San Francisco: Jossey-Bass.

Rubin, K. H., Fein, G. G., \& Vandenberg, B. (1983). Play. In P. H. Mussen (Series ed.), \& E. M. Hetherington (Vol. Ed.), Handbook of child psychology: Vol.4. Socialization, personality, and social development (pp. 693-774). New York: Wiley.

Sachs, J. (1980). The role of adult-child play in language development. In K. H. Rubin (Ed.), Children's play (pp. 33-48). San Francisco: JosseyBass.

Schwartzman, H. B. (1978). Transformations: The anthropology of children's play. New York: Plenum.

Schwartzman, H. B. (Ed.) (1980). Play and culture: 1978 proceedings of the anthropological study of play. West Point, NY: Leisure Press.

Sutton-Smith, B. (1971). Piaget on play: A critique. In R. E. Herron \& B. Sutton-Smith (Eds.) Child's play (pp. 326-336). New York: Wiley.

Sylva, K., Bruner, J. S., \& Genova, P. (1974). The role of play in the problem-solving of children 3-5 years old. In J. S. Bruner, A. Jolly, \& K. Sylva (Eds.) Play: Its role in development and evolution (pp. 244257). New York: Basic Books. 
Turner, V. (1967). The forrest of symbols. Ithaca: Cornell University Press.

Turner, V. (1969). The ritual process. Ithaca: Cornell University Press.

Turner, V. (1986). Carnavalin Rio: Dionysian drama in an industrializing society. In The anthropology of performance (pp. 123-138). New York: PAJ Publications.

Vandenberg, B. (1980). Play, problem-solving, and creativity. In K. H. Rubin (Ed.), Children's play (pp. 49-68). San Francisco: Jossey-Bass.

Vygotsky, L. S. (1967). Play and its role in the mental development of the child. Soviet Psychology, 12, 6-18. (A stenographic record of a lecture given in 1933; included in J. S. Bruner, A. Jolly, \& K. Sylva, eds., 1976; partly produced in Vygotsky, 1978.)

Vygotsky, L. S. (1978). Mind in society: The development of higher psychological processes (M. Cole, V. JohnSteiner, S. Scribner, \& E. Souberman, eds.). Cambridge, MA: Harvard University Press.

Vygotsky, L. S. (1986). Thought and language. Cambridge, MA: MIT Press.

Vygotsky, L. S. (1987). The collected works of L. S. Vygotsky: Vol. 1. Problems of general psychology (including the volume 'Thinking and Speech') (R. W. Rieber \& A. S. Carton, eds.: N. Mİnick, trans.). New York: Plenum Press.

Watson, M. W., \& Fischer, K. W. (1977). A developmental sequence of agent use in late infancy. Child Development, 48, 828-836.

Weintraub, J. (1974). Some reflections on Durkheim's concept of human nature: Preliminary expectorations. Unpublished manuscript. University of California, Berkeley.

Weintraub, J. (fourthcoming). Freedom and community: The republican virtue tradition and sociology of liberty. Berkeley: University of California Press.

Wertsch, J. V. (1985). The social formation of mind: A Vygotskian approach. Cambridge, MA: Harvard University Press. 